\title{
Controls on porosity preservation within a Jurassic oolitic reservoir complex, UAE
}

DOI:

10.1016/j.marpetgeo.2017.09.015

\section{Document Version}

Accepted author manuscript

Link to publication record in Manchester Research Explorer

\section{Citation for published version (APA):}

Hollis, C., Lawrence, D. A., Perière, M. D. D., \& Darmaki, F. A. (2017). Controls on porosity preservation within a Jurassic oolitic reservoir complex, UAE. Marine and Petroleum Geology, 88, 888-906.

https://doi.org/10.1016/j.marpetgeo.2017.09.015

\section{Published in:}

Marine and Petroleum Geology

\section{Citing this paper}

Please note that where the full-text provided on Manchester Research Explorer is the Author Accepted Manuscript or Proof version this may differ from the final Published version. If citing, it is advised that you check and use the publisher's definitive version.

\section{General rights}

Copyright and moral rights for the publications made accessible in the Research Explorer are retained by the authors and/or other copyright owners and it is a condition of accessing publications that users recognise and abide by the legal requirements associated with these rights.

\section{Takedown policy}

If you believe that this document breaches copyright please refer to the University of Manchester's Takedown Procedures [http://man.ac.uk/04Y6Bo] or contact uml.scholarlycommunications@manchester.ac.uk providing relevant details, so we can investigate your claim.

\section{OPEN ACCESS}




\title{
Controls on porosity preservation within a Jurassic oolitic reservoir complex, UAE
}

Cathy Hollis, University of Manchester; David A. Lawrence, Al Hosn Gas; Matthieu Deville de Perière, Badley Ashton \& Associates; Fatima Al Darmaki, Al Hosn Gas

\begin{abstract}
The Upper Jurassic Arab Formation, onshore southern UAE, comprises an upward-shallowing succession of slope to basinal wackestones (lower Arab D Member) oolitic grainstone (upper Arab D Member) and peritidal - subtidal carbonate-evaporites (Arab A-C Members). This study focuses on the upper Arab D Member, the volumetrically most important reservoir unit in the field, which is dominated by oolitic and skeletal oolitic grainstones with high porosity and moderate to low permeability. Through much of the upper Arab D Member, porosity has been inverted so that ooids are porous and interparticle macropores cemented by pre-compactional non-ferroan calcite. Cementation is most pervasive within cross-bedded skeletal oolitic grainstones, occluding primary interparticle macropores and biomoulds and penetrating the margins of altered ooids. In contrast, bioturbated pack-grainstones are often only partially cemented, and retain a well-connected primary interparticle macropore network.
\end{abstract}

Ooid alteration and porosity inversion in oolitic grainstones is often explained by open-system recrystallization by meteoric fluids during platform emergence. In this study, however, deposition took place in an arid basin that was eventually dessicated and hence the supply of groundwater would have been limited. The high concentrations of $\mathrm{Mg}$ and $\mathrm{Sr}$ within both the bulk rock limestone and cements suggest recrystallization could have occurred by marine pore fluids whilst, petrographical and geochemical homogeneity, including a narrow range of $\delta^{18} \mathrm{O}_{\text {calcite }}(-5 \% 0 \pm 1 \% 0)$, can be explained by closed-system stabilization of aragonite. Subsequent calcite cemented fractures and drusy, sparry pore filling calcite contain petroleum and aqueous inclusions with homogenisation temperatures up to $150^{\circ} \mathrm{C}$ The preservation of the highest macropore volumes on the palaeocrest of the field, and an off-flank 
reduction in porosity and permeability, suggests that oil emplacement terminated calcite cementation.

The results of this study demonstrate that a major reorganization of porosity can occur during the stablisation of metastable grains without invoking open-system circulation of meteoric water. Overall, the data provides an insight into possible controls on so-called porosity inversion, a poorly understood phenomenon in many hydrocarbon-bearing oolitic grainstone reservoirs.

Key words

Porosity inversion - oolitic grainstone - Arab D - closed system diagenesis 


\section{Introduction}

Carbonate sedimentation in the Upper Jurassic (Kimmeridgian to Tithonian) took place on a shallow water platform across the eastern Arabian Plate (Lindsey et al, 2006; Figure 1). This study is focused on the upper part of the Kimmeridgian Arab D Member (Azer and Peebles, 1998; Figure 2) in a giant onshore gas field, southern UAE. The field is a NE-SW trending, 70km long faulted anticline that formed during WNW-ESE compression in the Upper Cretaceous (Figure 1). The field was discovered in 1966 but was not exploited until recently because of the high concentrations of $\mathrm{H}_{2} \mathrm{~S}$ and $\mathrm{CO}_{2}$. Appraisal and development drilling has taken place since 2010 and the field came onstream in 2015. This paper focuses on how diagenetic modification of the upper Arab D Member influenced the generation and preservation of porosity. As well as being one of the first detailed diagenetic studies of the Arab D Member onshore UAE it also provides insight into how pore structure can be changed during closed system diagenesis, resulting in a net reorganization of porosity that reduced both pore size and permeability.

Prior to diagenesis, oolitic grainstones have the best reservoir potential of any carbonate sediments, since their clean texture and rounded grains facilitate ineffective packing, and hence preservation of large, well connected, primary interparticle macropores. As such, they are important reservoirs globally, particularly in the Permo-Trias (Khuff Formation; Inselaco et al., 2006), Jurassic (Smackover Formation; Moore and Druckman, 1981; Great Oolite Formation, eg. Sellwood et al.,1989; Arab Formation, Cantrell, 2006) and Lower Cretaceous (Davies et al., 2000). The structure and connectivity of the pore network within these reservoirs varies widely, however, from highly effective primary interparticle porosity (eg. Davies et al., 2000) to oomouldic porosity (Moore and Druckman, 1981), mixed macro- and microporous (Lucia et al., 2001; Cantrell, 2006; Cantrell and Haggerty, 1999) to low porosity and pervasively cemented (Heydari, 2003; Sellwood et al., 1989). A number of these studies identify coarser grain size (Lucia et al., 2001; Heydari, 2003), partial cementation (eg. Heydari, 2003) and hydrocarbon 
emplacement (eg. Sellwood et al., 1989; Heasley et al., 2000) as important controls on pore volume and connectivity.

Porosity inversion refers to the process whereby grain dissolution and cementation of interparticle macroporosity creates a poorly connected network of secondary intraparticle and mouldic porosity. It has been described from Recent sediments (Eberli et al., 2003), and so is known to occur early in the burial history. The petrophysical impact of this porosity inversion has been widely described, since the poor connectivity of oo-mouldic pores means there is potential to underpredict pore volumes from velocity data, including during seismic inversion, and to overestimate permeability from porosity data (eg. Eberli et al., 2003; Weger et al., 2009). The mechanism for forming such porosity is not well understood, however, even though this is critical to prediction of the spatial and temporal distribution of pore type and connectivity. In particular, grain dissolution or recrystallization, and concomitant occlusion of interparticle porosity, early in the burial history will reduce permeability, thereby inhibiting the subsequent flux of reactive fluids and changing diagenetic pathways.

\section{Tectonostratigraphic Setting}

The Arabian Plate was a passive margin during the Upper Jurassic. The study area is located on the southern margin of the plate, to the south of an intra-shelf basin that extended from present day Qatar to southeastern UAE (Ziegler 2001, Sharland et al., 2001 Figure 1). Carbonate sedimentation dominated the Arabian Plate throughout the Mesozoic, with periodic dessication of intrashelf basins during arid periods (Triassic and Jurassic) and clastic incursions from fluvial-deltaic systems sourced from the Arabian Shield during as humidity increased in the Cretaceous (Sharland et al., 2001; Figure 1). In the Upper Jurassic, there was a template of moderate to low energy carbonate and evaporite deposition under shallow subtidal and peritidal conditions, with an overall upward-shallowing as part of the second-order, AP7 tectono-stratigraphic megasequence of Sharland et al (2001) (Figure 2). 
The stratigraphic age of the Arab Formation onshore UAE is not well-constrained, so it is considered in this study to be equivalent to that for offshore UAE, Qatar and Saudi Arabia. Here, the Arab Formation comprises four carbonate-evaporite units, designated as the Arab D (Kimmeridgian) to A (Tithonian) Members (Azer \& Peebles, 1998; Figure 2). The Arab Formation within the studied field has moderate dips (5-15) and is bounded by reverse faults and flexures (Johnson et al., 2005). The Lower Arab D Member comprises mudstones, wackestones and skeletal rudstones deposited in a low energy, moderately deep slope-basinal, subtidal setting. The upper Arab D Member is dominated by skeletal oolitic grainstones deposited within a moderate to high energy tidal setting, whilst the Arab C - A Members comprise partially dolomitized fine grained peritidal carbonates capped by anhydrites (Figure 1). In the latest Tithonian, basin dessication led to precipitation of the Hith Anhydrite Formation, which forms a regional topseal (Al Silwadi et al., 1996; Ziegler, 2001: Figure 2).

The burial history of the field is not well constrained; maximum burial probably did not exceed $2 \mathrm{~km}$, prior to hydrocarbon migration and trapping that occurred in response to regional compression at the end of the Cretaceous - early Tertiary. This so-called First Alpine Event was associated with emplacement of the Semail Ophiolite complex, and was succeed by the Second Alpine Event in the Oligo-Miocene, resulting from closure of neo-Tethys and the onset of the Alpine Orogeny (Loosveld et al., 1996). In this field, oil charge is thought to have occurred in the late Cretaceous, followed by tectonic tilting to the north-east. The structure was then uplifted and reburied, prior to a second uplift event, where it was tilted and gas charged in the Oligo-Miocene.

\section{Depositional framework}

A depositional model and sequence stratigraphic framework for the Upper Arab D Member was presented by Lawrence et al (2015) and is summarized in Table 1, Figure $1 \mathrm{C}$ and Figure 3. Overall, six facies associations are interpreted to have been deposited along a south west-north east dipping, 
platform to basin transect from a shallow water, low energy lagoon fringed by ooid grainstone shoals and offshore slope and basinal peloidal skeletal pack-wackestones and lime mudstones.

The base of the upper Arab D Member (Lower Sequence Boundary, LSB) comprises a dolomitised lime mudstone that is $<3 \mathrm{~m}$ thick and capped by dolomitised reworked, bored, centimetre-scale dolomite clasts. The LSB is best developed in the southwest of the field and becomes more subtle to the northeast. Above the LSB, trough cross-bedded grainstones in the south-west pass laterally into planar laminated molluscan pack-grainstone (PGml; offshore active shoal) then basinal lime mudstone (MI) to the far north-east, suggesting that the platform dipped to the north-east. The upper part of this layer is characterized by a fieldwide blanket of peloidal packstone (foreshoal/slope) with a thin layer of basinal lime mudstone containing diffuse dark grey to black clay. Based on this, and an associated increase in gamma ray response, the interval is interpreted as a Maximum Flooding Zone (MFZ; Figure 2). This paper will focus on the succession above the MFZ, which is the main reservoir unit within the study field.

Above the MFZ, peloidal packstones (Pp) grade upwards into oolitic grainstone-dominated facies with trough cross-bedding (Got). The grainstones are thickest in the north eastern wells, whilst planar laminated oolitic skeletal grainstone facies (Gol) dominate in the southwest. Low angle lamination and accretion surfaces show southwest to westerly dips over most of the field with some dips to the northwest in the south (Lawrence et al., 2015). This suggests a tide-dominated, NW-SE trending shoreline protecting a back-barrier lagoon. The succession passes upward into stacked, subtly upwardfining beds of Facies Association Got, often with erosive bases, that host pebble-grade clasts and skeletal debris. A range of dip orientations suggests an active shoal dominated the entire area, comprising a network of parabolic bar forms which were dissected by tidal channels. The uniformity of facies across the field implies that carbonate productivity kept up with sea level, and there was no variation in topographic relief. At the top of the Upper Arab D Member, there is a transition from Facies Association Gol to PGob, suggesting slightly lower energy conditions, most likely within a shallow water 
lagoon. The sediments occur across the entire field, increasing in thickness from around $2 \mathrm{~m}$ in the southwest to $6 \mathrm{~m}$ in northeasterly wells. The layer is capped by an irregular surface that is characterised by intercalations of green clay and sub-angular to rounded pebble-grade clasts of peloidal oolitic grainstone, peloidal packstone and lime mudstone. This surface is interpreted as an emergent surface and is referred to as the Upper Sequence Boundary (USB) (Lawrence et al. 2015; Figure 2).

\section{Methods}

The database for this study included ten cored wells (Wells A-J), with approximately $1300 \mathrm{~m}$ of core that were supplemented by routine wireline logs and high-resolution resistivity image logs. Cores were logged in detail at 1:50 scale and sampled for petrographical analysis. Core plugs were taken every 30 $\mathrm{cm}$ for routine porosity and permeability measurements.

Standard 30 micron-thick thin sections were prepared with a blue-dyed resin impregnation to show porosity and stained with Alizarin Red and Potassium Ferrocyanide according to the method of Dickson (1966), a subset of which (90 samples) were point counted. This modal analysis was undertaken using an automated stage by counting 300 points (grains, authigenic phases and porosity) using an orthogonal grid system. The distance between points was variable and dependent on the thin-section area; the main criterion was to analyse most of the thin-section in 300 equally spaced points. In addition over 200 standard and 35 large format 40 micron thick polished sections were prepared for examination under cathodoluminescence $(C L)$. Polished thin sections were examined under CL using a Citl 8200 mark 2, with a voltage between 6-8 volts and a gun potential of $15 \mathrm{kV}$. The cathode current varied between $250 \mu \mathrm{A}$ and $350 \mu \mathrm{A}$. Scanning electron microscopy was conducted on carbon coated large format polished sections using a JEOL JSM-6400 SEM with Princeton Gamma Tech EDX system in backscatter mode at a pressure of $3.7 \mathrm{e}-6 \mathrm{mBar}, 15 \mathrm{Kv}$ and with a beam size of $5 \mu \mathrm{m}$.

Bulk trace element analysis for major ions ( $\mathrm{Mn}, \mathrm{Fe}, \mathrm{Mg}, \mathrm{Ca}, \mathrm{Sr}$ ) was conducted on hand-drilled samples, 
microsampled using a dentist drill. One hundred milligrams of sample were placed into reaction vessels, dissolved in $5 \mathrm{ml}$ of $20 \% \mathrm{HCl}$ and left to react overnight. A further $5 \mathrm{ml}$ of distilled water was then added and left to react overnight before a final dilution of $10 \mathrm{ml}$ distilled water. Samples were then spun in a centrifuge at $3000 \mathrm{rpm}$ for 3 minutes to separate any insoluble material and pipette in to ICP vials. Major elements were analyzed via ICP-AES and Rare Earth Elements (REE) by ICP-MS at the University of Manchester. All REE were normalised against the Post-Archean Australian Shale (PAAS) (Nance and Taylor, 1976).

Electron microprobe analysis (EMPA) was conducted on carbon coated polished sections using a Cameca SX 100 Electron Microprobe with an accelerating voltage of $15 \mathrm{Kv}$, beam current of $20 \mathrm{nA}$ and a beam width of $1 \mu \mathrm{m}$. Elemental maps were used to determine the relative distributions of selected elements, then transects selected to determine wt\% oxides ( $\mathrm{Mn}, \mathrm{Fe}, \mathrm{Mg}, \mathrm{Ca}, \mathrm{Sr}, \mathrm{Na}, \mathrm{Si}$ ). These values were converted to ppm for display purposes.

Carbon and oxygen stable isotope analysis was conducted at University of Liverpool. Samples were microdrilled using a handheld, tungsten-tipped dentist drill and placed into non-reactive plastic vessels. Samples of calcite were reacted to completion with phosphoric acid under vacuum, at temperatures of $25^{\circ} \mathrm{C}$. The isotopic ratio of carbon and oxygen from the released and captured $\mathrm{CO}_{2}$ were measured using a VG SIRA10 mass spectrometer. Isotope ratios were corrected for ${ }^{17} \mathrm{O}$ effects following the procedures of Craig (1957). Oxygen isotope data were adjusted for isotopic fractionation associated with the calcitephosphoric acid reaction using a fractionation factor $(\alpha)$ of 1.01025 (Friedman \& O'Neil, 1977). Samples were run against an internal standard and all results were reproducible to $+0.1 \% 0(2 \sigma)$. All data is reported relative to the PDB standard unless otherwise stated.

Fluid inclusion analysis of calcite and dolomite cements was conducted on five unstained, doublepolished, $100 \mu \mathrm{m}$ thick sections using a cooling/freezing stage linked to an optical microscope. Aqueous, 
two-phase primary inclusions were identified and homogeneisation temperatures (Th) measured by heating until the gas bubble disappeared. All heating runs were repeated four times and with .

\section{RESULTS}

\section{Porosity}

The Upper Arab D Member has good porosity (mean $=16.3 \%$, range= 2-30\%) and poor permeability (mean $=4.89$, range $=0.001-254 \mathrm{mD}$; Figure 4 and $5 \mathrm{~A}-\mathrm{B})$. The dominant pore type is intraparticle microporosity within ooids, which is typically oil stained (Figure 6)with subordinate primary interparticle macroporosity between ooids, rare mouldic porosity. Interparticle microporosity occurs within lime mud. Ooids occur in four forms:

1. Ooids with a well preserved concentric and radial fabric, either through the entire ooid or the outermost cortices (Figure 7A) with only minor or no intraparticle microporosity and often high interparticle macroporosity. Such unaltered ooids are rare, and tend to occur immediately below the USB, within Facies Association PGob, in particular within the vicinity of Well F and, to a lesser extent, Well I.

2. Ooids with a core of dense fused microcrystalline calcite with outer, porous microcrystalline calcite cortices (Fig 6E-F). Microcrystalline calcite within these cortices is 1-10 microns diameter, subhedral-euhedral and occasionally rounded. At the centre of the ooid, the calcite is subhedral to anhedral, amalgamated, fused and more coarsely crystalline ( $\sim 10$ microns; Figure $6 \mathrm{~B}$ and $6 \mathrm{~F})$. Where microporosity has been created on the margins of an ooid, the outer cortices may have been enlarged, creating a macroporous cortex (Figure 6E). These cortices may be partially or fully occluded by equant drusy and poikilotopic calcite that penetrates inwards from primary interparticle macropores (Figure 6B). Alternatively, the remnant cortices may become bent and spalled (Figure 6E). 
3. Entirely microporous ooids, comprising 1-10 microns diameter, subhedral-euhedral microcrystalline calcite (Figure 6D and 7B-D)

4. Oomoulds, which are rare and represent total dissolution, usually of the finest grained ooids. Typically, oomoulds are at least partially calcite cemented (Figure 6A).

Both porosity and permeability increase with increasing macroporosity(Figure $5 \mathrm{C}$ ). The highest porosity and permeability is preserved within Facies Association PGbo, and to a lesser extent Facies Association Gol, which have the highest volumes of primary interparticle and secondary macroporosity, respectively (Figure 5). Secondary macropores within Facies Associations Gol and Got are mostly biomoulds, formed by the dissolution of bivalves, usually within discrete laminae. Most biomoulds are now cemented by poikilotopic and equant, drusy calcite cement (Figure 6C). Primary macroporosity is absent within Facies Associations $\mathrm{Pp}$ and $\mathrm{Ml}$ and hence they typically have poor porosity and permeability (Figure 6B). However, Facies Associations PGml, Pp and Ml all have well developed secondary macropore networks around stylolites and tension gashes, in the form of leached microporosity and solution-enhanced primary interparticle macropores and moulds, after anhydrite (Hollis et al., 2017). These are not discussed further in this paper.

The highest volume of preserved macroporosity, and the highest permeability, is measured in and around Well F (Figure 4), which is to the north-east of the present day crest of the field. Porosity and permeability tend to decrease off-crest, with complete occlusion of most primary macro- and microporosity in Well D on the flank of the field, by calcite cementation and compaction (Figure 4). In general, porosity and permeability increase from low values at the USB to reach a maximum in the uppermost $10 \mathrm{~m}$ of most wells, before stabilizing to lower, less variable values at the MFZ (Figure 5A-B).

\section{Diagenetic fabric}


Ooids in this study only rarely preserve primary fabrics, principally at the top of the upper Arab D Member. They are particularly well preserved in the vicinity of well $F$, where concentric and radial fabrics are observed, usually surrounding a peloidal or micritised skeletal core (Figure 7A). More commonly, ooids are altered and hydrocarbon stained (Figures 6-7), although ghosts of the precursor concentric laminae may be visible. Under SEM, ooids comprise equant, euhedral to subhedral, microcrystalline calcite that is $\sim 1-5$ micron diameter (Figure $6 \mathrm{~B}$ and $\mathrm{F}$ ). Where these crystals are isolated, intercrystalline micropores up to 5 microns are preserved (Figure 6B and F). Under cathodoluminescence, ooids are non-luminescent.

Throughout most of the upper Arab D Member, high interparticle pore volumes are preserved in cemented oolitic and skeletal oolitic grainstones (Gol, Got) such that grains apparently float within the pore-occluding cements (e.g. Figure $6 \mathrm{~A}$ and $\mathrm{C}$ ). Where interparticle calcite cement has not been precipitated, ooids show elongated grain-grain contacts, may be compactionally deformed and often exhibit pressure dissolution seams (Figure 7B).

\section{Cementation}

Pore filling calcite cementation

Pore filling cements are usually abundant and dominated by non-ferroan calcite. In particular, pervasive cementation of primary interparticle and mouldic macroporosity occurs in the coarsest, skeletal-rich layers of Facies Associations Gol and Got (Figure 3). Petrographically, cements are extremely homogeneous and are differentiated on the basis of their crystal fabric and distribution. The cements have four principal forms (Figure 7):

1. Isopachous, elongate fibrous to columnar non ferroan calcite that partially to completely coats ooids and skeletal allochems forming thin rims that locally occlude pore throats. This cement is usually non-luminescent but can grade into dull and bright, concentrically zoned, luminescent 
calcite. This cement phase has a low volume and is enveloped by all the cements described below.

2. Syntaxial overgrowths, which are nucleated on echinoderm plates and partially to completely occlude primary interparticle macropores. They are coarsely crystalline with euhedral terminations and either uniformly dull or show a dull to bright luminescent concentric zonation under $\mathrm{CL}$.

3. Poikilotopic calcite is coarsely crystalline with subhedral to euhedral terminations and dullbright-dull concentric zonation or dull-bright sector zonation under CL. Poikilotopic calcite occludes primary interparticle macropores and intraparticle microporosity within oomoulds, locally replacing fine grained ooids and peloids.

4. Dull orange-brown luminescent, subhedral, moderately crystalline, equant, drusy calcite occludes primary and secondary (mouldic) porosity, intraparticle microporosity in ooids and locally replaces skeletal allochems. The cement does not display a clear paragenetic relationship with other calcite cements, although it is seen adjacent to impersistent fractures that are also cemented by equant, sparry, dull brown-orange luminesecent non ferroan calcite (Figure 7E-F). These fractures occur most commonly in the uppermost part of the Upper Arab D Member, and are narrow ( $\mathrm{mm}$-wide), short $(<5 \mathrm{~cm})$ and often en-echelon.

The petrographical similarity of the calcite cements, and the difficulty in reliably separating ooids and interparticle pore filling calcite for isotopic analysis means that isotopic fingerprinting of individual cement phases was not possible. Stable isotope analysis of whole rock oolitic grainstones measured $\delta^{13} \mathrm{C}=-1.5-2 \%$, with most samples tightly constrained to $\delta^{13} \mathrm{C}=1$ to $2 \%$ o and $\delta^{18} \mathrm{O}=-3.5$ to $-5.6 \% 0$ (Figure 8A). This is despite matrix pore filling calcite cement, non-skeletal grain and interparticle matrix volumes varying within these samples from $<10$ to $>60 \%$ (Figure $8 \mathrm{~B}$ ). Bulk rock ICP-AES trace element 
analysis measured low concentrations of $\mathrm{Mn}$ (mean=10; range $=5-12 \mathrm{ppm})$ and $\mathrm{Fe}$ (mean=114; range = 46-269ppm) but high concentrations of $\mathrm{Sr}$ (mean= 733; range $=180-4090 \mathrm{ppm})$ and $\mathrm{Mg}$ (mean= 4100; range $=1833-7463 p p m ;$ Figure 9 Table 2). In situ trace element analysis (EPMA) recorded similar concentrations of $\mathrm{Fe}, \mathrm{Mn}$ and $\mathrm{Mg}$ and more variable concentrations of $\mathrm{Sr}$ (Figure 10). The bulk rock cemented oolitic grainstones have a linear REE profile with a negative Ce anomaly and positive La anomaly and average $\Sigma_{\mathrm{REE}}=0.51 \mathrm{ppm}$ (range $=0.12-1.06 \mathrm{ppm}$; Figure 9). Primary, two-phase aqueous inclusions and petroleum inclusions were observed in some poikiloptopic and equant drusy calcite cements, although they are not ubiquitous. Homogenization temperatures range from $100-150^{\circ} \mathrm{C}$, with the lowest temperatures in Well $B\left(<130^{\circ} \mathrm{C}\right)$ and the highest in Wells $\mathrm{C}$ and $\mathrm{D}\left(130-150^{\circ} \mathrm{C}\right.$; Figure $\left.10 \mathrm{E}\right)$.

Calcite cements sampled from fractures are dull-brown luminescent, weakly zoned (Figure 7E-F) and contain hydrocarbon inclusions. They show more wide-ranging isotopic values than pore filling calcite $\left(\left(\delta^{18} \mathrm{O}=-2.8\right.\right.$ to $-6.2 \% 0 ; \delta^{13} \mathrm{C}=0.7$ to $1.6 \% 0, \mathrm{n}=4$; Figure $\left.8 \mathrm{~A}\right) . \mathrm{In}$ comparison, major ion concentrations (mean Fe= 272; Mn= 19ppm; $\mathrm{Sr}=620 \mathrm{ppm} ; \mathrm{Mg}=7114 \mathrm{ppm})$ and $\Sigma_{\mathrm{REE}}(0.41,0.25-0.56 \mathrm{ppm}$ ) are similar to pore filling calcite with a subtle depletion in HREE (Figure 9). Assuming a fluid temperature above $80^{\circ} \mathrm{C}$ (consistent with the presence of hydrocarbon inclusions), a crustal fluid composition $\left(\delta^{18} \mathrm{O}_{\mathrm{SMOW}}>+5 \% 0\right)$ is calculated from stable isotope data. Using the fluid inclusion temperatures of mineralogically and geochemically similar pore filling calcite of $>110^{\circ} \mathrm{C}$, fluid compositions are calculated to be even more enriched (>>8\%o SMOW).

\section{Discussion}

\section{Micropore generation}

Since intraparticle microporosity is the dominant pore type, determination of the timing of microporosity generation in ooids is critical to understanding porosity evolution in the upper Arab D Member. Compacted, and plastically deformed microporous ooids with elongate and microstylolitic 
grain contacts indicate that intraparticle microroporosity formed prior to compaction, whilst hydrocarbon staining of microporous ooids indicates alteration prior to oil charge. Penetration of micropores in ooids by non-ferroan, pokilotopic and equant, drusy calcite also demonstrates that microporosity formed prior to cementation of primary interparticle macroporosity by calcite. On petrographical evidence, therefore, the primary fabric of ooids must have been altered early in the burial history.

Two mechanisms can be considered to explain the alteration of the ooid cortices from their primary, radial-concentric fabric to microporous grains composed of microcrystalline calcite. Firstly, the grains could have been altered on the sea floor by infill of borings by endolithic algae by micrite, progressing to eventual destruction of the grain fabric. Although this process cannot be ruled out entirely, this does not provide an entirely satisfactory explanation for the ooid texture. Firstly, most of the ooids were deposited in a grainstone shoal, where wave action would have inhibited repeated boring, and fabric destruction. Secondly, ghosts of the original radial ooid fabric are often still visible; borings would have cut across these cortices and most likely destroyed the texture. Finally, the preferential preservation of ooid texture in some crestal wells cannot be adequately explained by this process; there is no good reason why some ooids would have remained unaltered despite deposition in the same shoal complex or in a protected lagoon, where microbial activity would have been most intense.

Alternatively, ooids could have been altered from a precursor, metastable phase to a microcrystalline calcite at some point after deposition. The Jurassic had a greenhouse climate and marked a transition from seawater that favoured aragonite and high magnesium calcite (HMC) precipitation to low magnesium calcite (LMC) seas (Hardie, 1996; Dickson, 2002). Even though seawater was largely calcitic by the late Jurassic, aragonite and $\mathrm{HMC}$ could still have been preferentially precipitated where $\mathrm{Mg} / \mathrm{Ca}$ were elevated since high concentrations of Mg2+ impedes calcite precipitation (e.g. Mucci and Morse, 1983). Widespread platform-scale dolomitisation and precipitation of gypsum/anhydrite in the Arab A-C 
(this study and Azer and Peebles, 1998; Lindsey et al., 2007; Cantrell, 2006) all suggest that a hot, arid climate dominated on the Arabian Plate during deposition of the Arab Formation, whilst the abundance of ooids is also indicative of elevated seawater salinity. It is entirely feasible, therefore, that many ooids formed asaragonite.

In modern sediments, freshwater can stabilize aragonitic grains to LMC very rapidly; Dravis (1986) refers to case-hardening of ooids within the vadose zone of modern sediments in a matter of decades. Similarly, Budd (1988) and Budd and Land (1990) showed that within Recent sediments in the Bahamas, ooids can be stabilized to LMC in the freshwater lens of ooid shoals in several hundred years. It is possible, therefore, that ooids within the upper Arab D Member were stabilized to LMC by groundwater soon after deposition. However, if the climate was arid, as suggested by the abundance of ooids and evaporite deposits in the Arab A-C, there would have been significantly less rainfall on the Arabian Plate than in the modern day Bahamas. Furthermore, aragonite transformation in modern Bahaman sediments occurs in narrow zones, within a freshwater lens that is up to a few metres thick (Budd and Land, 1990). Consequently, it is hard to see such a process resulting in a pervasive, nearly ubiquitous and field-wide, alteration of the ooids. Finally, geochemical data is inconsistent with stabilization of ooids by meteoric water. With the exception of samples at or close to the USB (-1 to $-3 \%$; Figure 8$)$, carbon isotopes have a seawater signature. If fluid-rock ratios were low, as they might be on an arid platform, then carbon isotopic values would have been rock-buffered. In this case freshwater alteration should be reflected by a low concentration of $\mathrm{Mg}$ ( $<4$ mol\%, Budd, 1989; Budd and Land, 1990) and Sr. In this study, however, bulk rock concentrations within the Upper Arab D of Mg (average 4 mol \%) and Sr ( up to $4092 \mathrm{ppm}$ ) are very high and other mechanisms need to be considered, as discussed below.

Timing of pore filling calcite cementation 
Isopachous, non-luminescent, grain rimming calcite predates all other calcite cements. Their morphology, distribution and non-luminescence are consistent with precipitation under oxic, moderate to high energy marine phreatic conditions. All other pore filling calcite cements have a relatively uniform petrographical appearance and geochemical composition (Figure 8-9). In particular, the weak dull-bright(-dull) luminenscence of most cements, regardless of morphology (syntaxial overgrowths, poikilotopic and equant, drusy calcite cements) implies little spatial or temporal variability in fluid composition. The low measured concentrations of $\mathrm{Mn}$ and Fe suggests either precipitation under oxic conditions or low concentrations of these elements in solution. The narrow carbon isotopic range is suggestive of cementation from marine porewaters or within a rock-buffered system. The high concentrations of $\mathrm{Mg}$ and $\mathrm{Sr}$ and negative Ce anomaly, positive La anomaly and increase in HREE compared to MREE is consistent with cementation from seawater (Hayley et al., 2000), whilst $\operatorname{Pr} / \operatorname{Pr} *$ vs $\mathrm{Ce} / \mathrm{Ce}$ * ratios plot in the marine quadrant (Figure 9D).

The moderate to coarse crystallinity of most pore filling cements reflects slow rates of cementation, and their occurrence within oomoulds and biomoulds, after molluscs, indicates that they postdate grain dissolution and neomorphism. The preservation of high interparticle volumes by calcite cements suggests cementation prior to mechanical compaction or preservation of high interparticle volumes during burial by overpressuring. Although the overlying Arab A-C Members have a low permeability, and are sealed by the Hith Anhydrite, overpressuring is ruled out because mechanical and chemical compaction is evident within oolitic grainstone beds that are not cemented (Figure 7A-B). The limited, localized evidence of chemical compaction makes it highly unlikely that calcite-saturated fluids were intraformationally derived from pressure dissolution. Consequently, it is necessary to identify a source of reactive fluid capable of precipitating calcite cement that comprises over $30 \%$ of the rock volume, under apparently suboxic, burial conditions. 
It has been argued that there is little geochemical or petrographical evidence for ooid alteration by freshwater within the upper Arab D Member, and that such a process would anyway have been unlikely in the arid conditions that dominated during and after deposition. At such an early stage in the burial history, prior to compaction and hydrocarbon emplacement, the only fluid that would have been available, therefore, would be seawater. Modern seawater is supersaturated with respect to aragonite, but dissolution can occur in the shallow subsurface as a result of microbial respiration and organic matter oxidation and bacterial sulphate reduction (Walter et al., 1993). During the Jurassic, the Mg/Ca ratio of seawater decreased and by the late Jurassic was probably calcitic (Hardie, 1996). Therefore, although some skeletal grains were precipitated as aragonite, marine pore waters were probably undersaturated with respect to aragonite. Whilst the preferential dissolution of aragonite and HMC will be strongly influenced by the saturation state of the fluid, Walter (1995) showed that dissolution will occur preferentially in aragonitic grains with higher microstructural complexity (i.e. smaller crystal size with more abundant primary intraparticle microporosity) than calcitic grains, since these grains have a higher reactive surface area and surface roughness. It is possible to envisage, therefore, that ooids and molluscan grains, with their complex microstructures, would be the first phases to undergo dissolution in the shallow burial realm.

The replacement of aragonite by LMC is essentially a dissolution - re-precipitation reaction, in which there is net porosity preservation, although there is growing evidence that this is a complex, multistaged process (eg. Lucia and Loucks, 2013; Lucia, 2017). Under high fluid-rock ratios, and good matrix permeability, complete dissolution of aragonite grains may create a void; the solute will then flux away from the pore, which can remain open (i.e. form mouldic porosity) or become cemented (Bathurst, 1975; Wilkinson et al., 1984). Under lower fluid-rock ratios, however, supersaturation with respect to LMC might be reached rapidly in the vicinity of the dissolving grain, leading to local re-precipitation of calcite and fabric preservation. The micro-crystalline LMC that replaces ooids within the upper Arab D 
Member suggests such a process, which may have been further facilitated by the high reactive surface area within ooids, providing a large number of sites for calcite nucleation.

The $\mathrm{Pr} / \mathrm{Pr}^{*}$ vs $\mathrm{Ce} / \mathrm{Ce}$ * ratios and $\mathrm{REE}$ profiles of the bulk rock limestones of the Arab $\mathrm{D}$ Member are distinctly marine, yet flattening of the HREE profile (Figure 10) is typical of reduced levels of oxygenation within the sediment pile (Hayley et al., 2004). The high concentration of Mg (average $\sim 4 \mathrm{~mol} \%$,) and Sr (average $\sim 700 \mathrm{ppm}$ ) of whole rock oolitic grainstone is strongly indicatative of diagenetic modification from marine porewaters. At high fluid-rock ratios, both elements would be retained within the pore fluid since they both have a distribution coefficient of <1 (Katz, 1973; Lorens, 1981). At low fluid-rock ratios, however, both $\mathrm{Mg}$ and $\mathrm{Sr}$ will become highly concentrated within the pore fluid. $\mathrm{D}_{\mathrm{Mg}}$ increases with temperature, and so as the concentration of $\mathrm{Mg}$ within the fluid increased, higher concentrations could have been incorporated into calcite. Even though $D_{s r}$ decreases with increasing temperature, an increased concentration of $\mathrm{Mg}$ within calcite can also facilitate incorporation of $\mathrm{Sr}$ in the calcite lattice (Mucci and Morse, 1993). Consequently, dissolution of aragonitic ooids at low fluid rock ratios is interpreted to have led to precipitation of calcite with a wide range of, but often high, concentrations of Mg and Sr.

If aragonite-calcite transformation took place during burial, then a temperature-controlled fractionation should be recorded in the neomorphic calcite, yet no variation in $\delta^{18} \mathrm{O}_{\text {calcite }}$ is seen, even between facies associations thathavevery different volumes of calcite cement (Figure 8A-B). Using the equation of Swart (2015 and references therein) it is possible to determine how fluid composition might evolve during aragonite dissolution under low fluid-rock ratios:

$\delta w e=\underline{M c R}[\delta C+1000(1-\alpha)]+M w \delta w i$

$M w+$ McatR 
Where $\delta$ we $=\delta^{18} \mathrm{O}_{\text {water }}$ of pore fluid after dissolution, $\mathrm{Mc}=$ mole fraction of oxygen in carbonate, $\mathrm{Mw}=$ mole fraction of oxygen in water, $\delta \mathrm{C}=\delta^{18} \mathrm{O}$ of initial sediment in $\mathrm{SMOW}, \delta \mathrm{wi}=$ initial $\delta^{18} \mathrm{O}_{\text {water, }} \mathrm{R}=$ amount of transformation, $\mathrm{a}=$ fractionation factor between calcite and water at temperature, $\mathrm{t}$.

An initial seawater with $\delta^{18} \mathrm{O}_{\text {water }}=-1 \%$ and $\delta^{18} \mathrm{O}_{\text {calcite }}=-5 \%$ at $33^{\circ} \mathrm{C}$, reacting with $20 \%$ of the original sediment at $40^{\circ} \mathrm{C}$ (equivalent to $280 \mathrm{~m}$ burial at a geothermal gradient of $25^{\circ} \mathrm{C} \mathrm{km}^{-1}$ ) would result in a porewater with $\delta^{18} \mathrm{O}_{\text {water }}=+1.2 \%$, increasing to $+2.1 \%$, by $60^{\circ} \mathrm{C}(1080 \mathrm{~m}$ burial $)$ assuming $90 \%$ aragonite transformation (Figure 8C). Based on Friedman and $\mathrm{O}^{\prime} \mathrm{Neil}(1977), \delta^{18} \mathrm{O}_{\text {calcite }}=-5 \%$ will precipitate from porewater with $\delta^{18} \mathrm{O}_{\text {water }}=+0.3 \%$ at $40^{\circ} \mathrm{C}$, and $\delta^{18} \mathrm{O}_{\text {water }}=+2.0 \%$ at $50^{\circ} \mathrm{C}$. Therefore to ensure a homogeneous $\delta^{18} \mathrm{O}_{\text {calcite }}=-5 \% 0 \pm 1 \% 0$ most aragonite transformation must have occurred before $\sim 1000 \mathrm{~m}$ of burial $/ 60^{\circ} \mathrm{C}$. This would be consistent with the apparent pre-compactional precipitation of calcite, preserving high interparticle volumes.

Neomorphosed ooids in this study typically have a dense, cemented core of microcrystalline LMC, but outer cortices are microporous, or even macroporous. Perhaps, therefore, there was initial precipitation of calcite within the centre of ooids, but towards the outer margins, diffusion moved solute away from the grain and into the interparticle pore network. Here fluids could have fluxed away from the reaction site via the primary interparticle macropore network or initiated precipitation of coarsely crystalline calcite, once fluids reached supersaturation. These cements occlude many interparticle macropores and their outer rims also penetrate open porosity within the ooid cortices and oomoulds, suggesting growth from the primary interparticle macropore into secondary intraparticle porosity within the ooid (Figure 6A and E). Although fluid convection may have occurred within the reservoir, support for local precipitation of calcite comes from the observation that where ooids are not altered to microcrystalline LMC, pore filling calcite cements are less abundant or absent. Furthermore, cementation is more pervasive within skeletal laminae of Facies Associations Gol and Got, than within oolitic laminae. In these facies, the dissolution of precursor aragonitic skeletal grains is likely to have further increased fluid 
saturation leading to very localized re-precipitation in the vicinity of the leached bioclasts. As such, this earliest stage of diagenesis appears to have taken place in a closed system, with localized redistribution of carbonate cements and porosity resulting from localized, probably diffusive, fluid transport. This is consistent with observations in more recent (Miocene-Pliocene) sediments from the Great Bahama Bank, where there is no evidence for the net import of carbonate during the transformation of aragonite transformation to calcite (Westphal et al., 2000; Lucia and Loucks, 2013; Lucia, 2017)

\section{Onset of late burial diagenesis}

The isotopic composition of the pore fluid at $\sim 1000 \mathrm{~m}$ burial $/ 60^{\circ} \mathrm{C}$ has been calculated as $\sim 2 \%$ SMOW. However, homogenization temperatures of $100-150^{\circ} \mathrm{C}$ within aqueous fluid inclusions, and the presence of petroleum inclusions within poikilotopic and equant, sparry calcite cements provide clear evidence that fluid temperatures eventually exceeded $60^{\circ} \mathrm{C}$. The reservoir attained maximum burial of $\sim 2 \mathrm{~km}$ in the Late Cretaceous, which implies reservoir temperatures never exceeded $\sim 85^{\circ} \mathrm{C}$. Consequently, an influx of hot, hydrocarbon-charged fluids must have occurred, most likely prior to or during the First Alpine event based on regional observations (Loosveld et al, 1996).

Fracture filling calcite cements petrographically resemble pore filling calcite (dull orange-brown luminescent, equant, sparry, non ferroan calcite), and have similar concentrations of Fe (272ppm), Mn (19ppm) and $\mathrm{Sr}(620 \mathrm{ppm})$ but higher $\mathrm{Mg}(7 \mathrm{~mol} \%)$ and a wider range of $\delta^{18} \mathrm{O}_{\text {calcite. Total }}$ REE concentrations are lower than bulk rock limestone and the HREE profile subtly more suppressed. This would suggest an influx of hot, hydrocarbon-charged, Mg-enriched brines via fractures into the Arab D Member. The homogeneity of the cement textures and the lack of differentiation in geochemical signature implies fluid mixing and homogenization, perhaps via convection in the residual interparticle macropore network. Eventually, as fluids reached supersaturation, much of the fracture and the remainder of the macropore network was occluded by calcite. 
It has been noted that the highest porosity and permeability occurs in the least altered, least cemented oolitic grainstones in Well F, which exhibit a well-connected primary interparticle pore network. Many of the ooids within this well remain unaltered, whilst primary interparticle macropores are open, rather than having been destroyed by compaction. Well $\mathrm{F}$ is positioned on the palaeo-crest of the field, which is interpreted to have been tilted during the $2^{\text {nd }}$ Alpine Event in the Oligo-Miocene. It is hypothesized, therefore, that the ingress of hydrocarbon terminated calcite cementation on the crest of the field and preserved macroporosity. This is consistent with the marked decrease in porosity and permeability within flank wells (eg. Wells D and J), which are pervasively cemented (Figure 4).

\section{Model for the evolution of porosity in the Upper Arab D Member}

In summary, a conceptual model is presented here of closed system diagenesis, which resulted in wholesale reorganization of the pore network within the Upper Arab D Member during burial. At deposition, ooids were predominantly composed of aragonite, as were some skeletal grains, particularly molluscs. Although there may have been some boring and micritisation of grains prior to burial, there is no reliable evidence that this was extensive. Rather, ooids often developed a thin, almost continuous coating of prismatic, grain rimming non-ferroan calcite. High sedimentation rates, particularly within the ooid shoal complex led to rapid burial, where the onset of organic oxidation, and then bacterial sulphate reduction increased the $\mathrm{pH}$ of pore fluids and initiated dissolution of aragonite within ooids and skeletal grains (Figure 11A-B). Disequilibrium was driven by the high solubility of aragonite, which drove porewaters towards calcite saturation. Microcrystalline calcite was precipitated within the core of ooids, forming a dense, interlocking microcrystalline calcite core, whilst a more open, microporous fabric formed on the outer cortices of ooids. Ongoing dissolution continued to precipitate fabricdestructive or weakly fabric retentive microcrystalline non ferroan calcite within ooids, with diffusion of pore fluids outwards into the primary interparticle pore network (Figure 11C). There was a consequential increase in calcite saturation in the interparticle pore network, leading to precipitation of 
coarsely crystalline, subhedral to euhedral calcite (Figure 11D1). This cement occluded primary and secondary interparticle and intraparticle macropores but preserved interparticle volumes. Where cementation did not occur, compaction proceeded, reducing pore size and connectivity (Figure 11D2 and 11E1). Cementation of interparticle macroporosity was sustained into the burial realm by the influx of hot, hydrocarbon-bearing brines, leading to pervasive cementation of the pore network (Figure 11E2). On the palaeocrest of the field, the onset of oil emplacement modified wettability and apparently terminated cementation (Figure 11E3), whilst aqueous diagenesis continued to occlude porosity on the flanks of the field.

\section{Broader Implications}

Melim et al (1995) and Melim et al (2002) demonstrated that diagenetic modification of carbonate sediments during the earliest stages of burial, with marine porewaters, can produce textures that resemble those formed from freshwater. This process is often overlooked in the interpretation of ancient sediments, and this study provides an example of where it may play a fundamental role in controlling pore architecture. It may be of particular significance within carbonate sediments deposited within relatively arid settings, in a greenhouse climate, where sea level fluctuations are infrequent and rainfall low. Under these conditions, infiltration of rainwater in the vadose zone would be minor and the freshwater lens would be shallow, inhibiting widespread stabilization of aragonite.

Closed system stabilization of aragonite provides a mechanism for pervasive alteration of the rock fabric through remobilization of calcium carbonate in the earliest stages of burial. In this study, the process appears to be complete within the first kilometre of burial $\left(\sim 60^{\circ} \mathrm{C}\right)$. At this point, diagenetic modification became controlled by the import of fluids, in this case hydrocarbon bearing brines along fractures that terminated cementation once hydrocarbons were in place.

Consequently, although marine diagenesis is unlikely to explain how intraparticle microporosity formed 
in all oolitic grainstone reservoirs, it is a process that has no doubt been overlooked. For example, Sellwood et al (1989) and Sellwood and Beckett (1991) interpreted alteration of the mid-Jurassic Great Oolite Limestone by mixing of meteoric and marine porewaters with $\delta^{18} \mathrm{O}_{\text {water }} \sim-2 \%$ SMOW apparently beneath emergent surfaces. Interestingly, the isotopic ratios they measure $\left(\delta^{18} \mathrm{O}_{\text {carbonate }}=-4\right.$ to $-6 \%$ ) resemble those determined in this $\operatorname{study}\left(\delta^{18} \mathrm{O}_{\text {carbonate }}=-4.6\right.$ to $\left.-5.8 \% 0\right)$, even though the Great Oolite Formation was deposited at higher latitudes, and would therefore have interacted with isotopically lighter rainwater, than the sub-equatorial Arab Formation. If closed system alteration of ooids had occurred from seawater, this similarity in isotopic composition could be explained. Moore and Druckman (1981) acknowledge that a model of porosity inversion by meteoric fluids is incompatible with the arid palaeoenvironment in which the Upper Jurassic (Oxfordian) Smackover Formation was deposited, as well as with their measured $\delta^{18} \mathrm{O}_{\text {carbonate }} \sim-4 \%$ and $\delta^{13} \mathrm{C}_{\text {carbonate }} \sim+2-+4 \%$, and other models of porosity redistribution have since been proposed, including redistribution of calcium carbonate during burial and chemical compaction (e.g. Heydari, 2000). Again, the similarity in $\delta^{18} \mathrm{O}_{\text {carbonate }}$ to the Arab Formation is strikingCantrell (2005) recognized intra-cortical porosity in ooids within the Arab Formation in Saudi Arabia and emphasized that the absence of evidence for meteoric diagenesis, consistent with the arid climate at the time of deposition. In all these cases, redistribution of porosity during burial through the alteration of grains within marine-derived porewaters is an alternative mechanism for explaining porosity distribution, particularly in successions with a mixed aragonite-calcite mineralogy.

\section{Conclusions}

1. The upper Arab D reservoir within the study area is dominated by oolitic grainstones deposited in an active oolitic shoal on the margins of an intrashelf basin

2. The ooids, and some skeletal grains, were deposited with an aragonitic mineralogy, which became metastable during the early stages of burial. Disequilibrium was established by 
aragonite dissolution, leading to supersaturation with respect to calcite

3. Diffusion of calcite-saturated fluids led to neomorphism of ooids to form microcrystalline grains and export of fluids to the interparticle pore network. Medium to coarsely crystalline calcite precipitated within the macropore network, inhibiting compaction

4. Where cementation was limited, sediments were compacted, particularly within the upper parts of the reservoir layer. However, early ingress of hydrocarbon in the palaeocrest of the field both terminated cementation and inhibited compaction, leading to preferential preservation of macroporosity and formation of a 'sweet-spot' within the present day reservoir. This is slightly offset from the present day crest of the field as a result of tilting in the Oligo-Miocene, prior to gas charge.

5. Towards the flanks of the field, cementation and compaction continued, drastically reducing reservoir quality.

6. Closed system reorganization of porosity within the marine diagenetic and early burial realm provides an alternative explanation to the more conventional assumption of meteoric stablisation of metastable grains, purported for many age-equivalent reservoirs. It provides a better explanation of the isotopic and trace element composition of the reservoir, and provides a mechanism for wholesale alteration of sediments that were rapidly deposited in an arid climate, where the ingress of freshwater is likely to be limited and localized.

\section{Acknowledgements}

The authors would like to thank Al Hosn Gas and Oxy for permission to publish this work. Technical support from Al Hosn Gas, Weatherford Laboratories, Badley Ashton \& Associates and University of Manchester is also acknowledged. Steve Crowley at University of Liverpool is also thanked for stable 
isotope analysis. Jeroen Kenter, an anonymous reviewer and Associate Editor Hildegard Westphal are thanked for their review and handling of this manuscript.

\section{References}

Alsharhan, A.S. and Nairn, A.E.M. 1997. Geology and Hydrocarbon Habitat in the Arabian Basin: Mesozoic of the State of Qatar. Geologie en Mijnbouw, v. 72, p. 265-294.

Al Silwadi, M.S., Kirkham, A., Simmons, M.D. and Twombley, B.N., 1996. New Insights into Regional Correlation and Sedimentology, Arab Formation (Upper Jurassic), Offshore Abu Dhabi. GeoArabia, v. 1, p. 6-27.

Azer, S.R. and Peebles, R.G., 1998. Sequence Stratigraphy of the Arab A to C Members and Hith Formation, Offshore Abu Dhabi. GeoArabia, v. 3, p. 251-268.

Bathurst, R., 1975. Carbonate sediments and their diagenesis (second edition). Elsevier, 658pp

Budd, D., 1988. Petrographic products of freshwater diagenesis in Holocene ooid sands, Schooner Cays, Bahamas. Carbonates and Evaporites, 3, 107-128

Budd, D. and Land, L., 1990, Geochemical imprint of meteoric diagenesis in Holocene ooid sands, Schooner Cays, Bahamas: Correlation of calcite cement geochemistry with extant groundwaters. Journal of Sedimentary Petrology, 60, 361-378

Cantrell, D and Hagerty, R., 1999. Microporosity in Arab Formation carbonates, Saudi Arabia. GeoArabia, $4,129-154$

Cantrell, D., 2006, Microporosity in Arab Formation Carbonates, Saudi Arabia. GeoArabia, 4, Davies, R., Hollis C., Bishop, C., Gaur, R. and Haider, A.A., 2000. Architecture of the Minagish Oolite reservoir in the Umm Gudair Field, West Kuwait. In: Middle East models of Jurassic/Cretaceous 
carbonate systems (Ed. A. Alsharan and R. Scott), SEPM Special publication 69.

Dickson, J.A.D., 1966, Carbonate identification and genesis as revealed by staining. Journal of Sedimentary Petrology, 36, 491-505

Dickson, J.A.D., 2002. Fossil echinoderms as monitor of the $\mathrm{Mg} / \mathrm{Ca}$ ratio of Phanerozoic oceans. Science, $298,1222-1224$

Dravis, J., 1996. Rapidity of freshwater calcite cementation- implications for carbonate diagenesis and sequence stratigraphy. Sedimentary Geology, 107, 1-10

Eberli, G., Anselmetti, F. and Incze, M., 2003. Factors controlling elastic properties in carbonate sediments and rocks. The Leading Edge, July 2003, 654-660

Friedman, I. and O'Neil, J.R., 1977. Compilation of stable isotope fractionation factors of geochemical interest. In: Data of Geochemistry, (Ed. M. Fleischer), USGS Professional Paper, 440-KK, 12pp

Hardie, L., 1996, Secular variation in seawter chemistry: an explanation for the coupled secular variation in the mineralogies of marine limestones and potash evaporates over the past 600my. Geology, 24, 279

Hayley, B., Klinkhammer, G and McManus, J., 2000. Rare earth elements in pore waters of marine sediments. Geochemica et Cosmochimica Acta, 68, 1265-1279

Heydari, E., 2000. Porosity loss, fluid flow and mass transfer in limestone reservoirs: Application to the Upper Jurassic Smackover Formation, Mississippi. AAPG Bulletin, 84, 100-118

Hollis, C Lawrence, C., Al Damarki, F., Deville de Perriere, M., Foote, A and Kostic, B., 2017. Origin of complex carbonate pore systems and associated reservoir quality variations from the Arab Formation (Upper Jurassic), onshore United Arab Emirates. SPE-188739-MS, presented at ADIPEC 2017, UAE, $13^{\text {th }}$ $16^{\text {th }}$ November 2017

Johnson, C.A., Hauge, T., Al Menhali, S., Bin Sumaidaa, S., Sabin, B. and West, B., 2005. Structural Styles 
and Tectonic Evolution of Onshore and Offshore Abu Dhabi, UAE. IPTC 10656.

Katz, A., 1973. The interaction of magnesium with calcite during crystal growth at $25-980 \mathrm{c}$ and one atmosphere. Geochimica et Cosmochimica Acta, 37,1563-1586

Lawrence, D., Hollis, C., Green, D., Deville de Perière, M., Al Darmaki, F., Bouzida, Y., 2015, Paleogeographic reconstruction of a tide-dominated oolite shoal complex in the Lower Arab Formation, onshore UAE. ADIPEC, 9-12 ${ }^{\text {th }}$ November 2015, SPE-177194-MS

Lindsay, R.F., Cantrell, D.L., Hughes, G.W., Keith, T.H., Mueller, H.W. III and Russell, S.D., 2006. Ghawar Arab-D Reservoir: Widespread Porosity in Shoaling-upward Carbonate Cycles, Saudi Arabia. In P.M. Harris and L.J. Weber, eds., Giant Hydrocarbon Reservoirs of the World: From Rocks to Reservoir Characterization and Modeling. AAPG Memoir 88 / SEPM Special Publication, p. 97-137.

Inselaco, E., Virgone, A; Courme, B, Gaillot, J, Kamali, M,; Moallemi, A, Lotfpour, M, Monibi, S. 2006, Upper Dalan Member and Kangan Formation between the Zagros Mountains and offshore Fars, Iran; depositional system, biostratigraphy and stratigraphic architecture. GeoArabia, 11, 75-176

Loosveld, R., Bell, A and Terken, J., 1996. The tectonic evolution of interior Oman. GeoArabia, 1, 28-51

Lorens, R., 1981. Sr, Cd, Mn and Co distribution coefficients in calcite as a function of calcite precipitation rate. Geochimica et Cosmochimica Acta, 45, 553-561

Lucia, J.F., Jennings, J.W. Jr., Rahnis, M. and Meyer, F.O., 2001. Permeability and Rock Fabric from Wireline Logs, Arab D Reservoir, Ghawar Field, Saudi Arabia. GeoArabia, v. 6, p. 619-646.

Lucia, J.F. and Loucks, R., 2013. Micropores in carbonate mud: early development and petrophysics. GCAGS Journal, 2, 1-10.

Lucia, J.F., 2017. Observations on the origin of micrite crystals. Marine and Petroleum Geology, 86, 823833 
Melim, L., Swart, P and Maliver, R., 1995. Meteoric-like fabrics forming in marine waters: Implications for the use of petrography to identify diagenetic environments. Geology, 23, 755-758

Melim, L., Westphal, H., Swart, P., Eberli, G and Munnecke, A., 2002, Questioning carbonate diagenetic paradigms: evidence from the Neogene of the Bahamas. Marine Geology, 185, 27-53

Moore, C. and Druckman, 1981. Burial diagenesis and porosity evolution, Upper Jurassic Smackover, Arkansas and Louisiana. AAPG Bulletin, 597-627

Mucci, A and Morse, J., 1983. The incorporation of $\mathrm{Mg}^{2+}$ and $\mathrm{Sr}^{2+}$ into calcite overgrowths: influences of growth rate and solution composition. Geochimica et Cosmochimica Acta, 47, 217-233

Nance, W and Taylor, S., 1976. Rare earth element patterns and crustal evolution - I. Australian postArchean sedimentary rocks. Geochimica et Cosmochimica Acta, 40, 1539-1551

Prokoph, A., Shields, G. and Veizer, J., 2008. Compilation and time-series analysis of a marine carbonate $\delta^{18} \mathrm{O}, \delta^{13} \mathrm{C},{ }^{87} \mathrm{Sr} /{ }^{86} \mathrm{Sr}$ and $\delta^{34} \mathrm{~S}$ database through Earth History. Earth Science Reviews $87,113-133$

Sharland, P.R., Archer, R., Casey, D.M., Davies, R.B., Hall, S.H., Heward, A.P., Horbury, A.D. and Simmons, M.D., 2001. Arabian Plate Sequence Stratigraphy. GeoArabia Special Publication 2, Gulf PetroLink, Bahrain, $371 \mathrm{p}$.

Sellwood, B., Shepherd, T., Evans, M and James, B., 1989. Origin of late cements in oolitic reservoir facies: a fluid inclusion and isotopic study (mid-Jurassic, southern England). Sedimentary Geology, 61, 223-237

Sellwood, B. and Beckett, D., 1991. Ooid microfabrics: the origin and distribution of high intra-ooid porosity; Mid-Jurassic reservoirs, S. England. Sedimentary Geology, 71, 189-193

Swart, P., 2015. The geochemistry of carbonate diagenesis: the past, present and future. Sedimentology, 62, 1233-1304 
Walter, L., Bischof, S., Patterson, W and Lyons, T., 1993. Dissolution and recrystallization in modern shelf carbonates: evidence from pore water and solid phase chemistry. Philosophical Transactions: Physical Sciences and Engineering, 344, 27-36

Walter, L., 1985. Relative reactivity of skeletal carbonates during dissolution: implications for diagenesis. In: Carbonate Cements (Edited N. Schneidermann and P. Harris). SEPM Special Publication, 36, 3-16

Weger, R., Eberli, G., Baechle, G., Massaferro, J and Sun, Y-F., 2009. Quantification of pore structure and its effect on sonic velocity and permeability in carbonates. AAPG Bulletin, 93, 1297-1317

Westphal, H., Head, M and Munnecke, A., 2000. Differential diagenesis of rhythmic limestone alternations supported by palynological evidence. Journal of Sedimentary Research, 70, 715-725

Wilkinson, B., Buczynski, C and Owen, R., 1984. Chemical control of carbonate phases: implications from Upper Pennsylvanian calcite-aragonite ooids of southeastern Kansas. Journal of Sedimentary Petrology, $54,932-947$

Ziegler, M.A., 2001. Late Permian to Holocene Paleofacies Evolution of the Arabian Plate and its Hydrocarbon Occurrences. GeoArabia, v. 6, p. 445-504. 
Figures

Figure 1 a) Location of field in southern UAE based on palaeogeographic map of Ziegler (1981), b) schematic view of the field, with isochores illustrating relative depth, and position of wells c) conceptual palaeogeography of the field during deposition of the Arab Formation, based on data from this study as discussed in Lawrence et al (2015)

Figure 2A) Regional stratigraphy, showing Arab Formation within Kimmeridgian AP7 sequence of Sharland et al. (2001) B) Field stratigraphy illustrated on a type log illustrating the position of the Upper Arab $D$ reservoir and interval of study (vertical red bar). USB= upper sequence boundary, $L S B=$ lower sequence boundary, MFZ= maximum flooding zone, as determined in this study

Figure 3 A Type log of the upper Arab D Member showing characteristic gamma ray (0-100API) and density $(1.95-2.95 \mathrm{~g} / \mathrm{cc})$ response and principal facies associations. Colours in the log correspond to the facies illustrated in the photomicrographs with lime mudstone (brown) not illustrated. USB= upper sequence boundary, LSB= lower sequence boundary, MFZ= maximum flooding zone, as determined in this study. B) Facies Association PGob, showing diffuse bioturbation (arrows in B1), and differential cementation of burrows (a in B2, delineated by yellow dashed lines). C) Facies Association Gol, with planar lamination (arrows in C1), defined by alternating skeletal-rhc laminae (a in C2) and oolitic-rich laminae D) Facies Association Got, defined with trough cross-lamination (arrows in D1), defined by alternations of undercompacted and cemented skeletal-rich laminae ( $a$ in D2, delineated by yellow dashed lines) and more compacted, oolitic-rich laminae (b in D2) E) Facies Association PGml, characterized by thin-shelled bivalves (arrows in E1 and E2) F) Facies Association Pp, which is largely featureless in core (F1) and characterized by abundant peloids in thin section (F2). Black scale bars on core photographs $=5 \mathrm{cmFigure} 4$ Porosity and permeability of cored wells, coded by facies association. All wells show data plotted by Facies Association. Note that wells within the crest and palaeocrest of 
the field (e.g Wells B and F) have higher porosity and permeability than off-crest (e.g. Well I) and flank wells (e.g. Well D). Photomicrographs show the decrease in total and interparticle macroporosity from crest (Well F) to flank (Well D) as a result of cementation. In Well F, interparticle micropores are abundant (a), and ooids are only partially microporous (b). The absence of cement has led to some compaction of grains and spalling of outer cortices of ooids (arrowed). In Well I, cementation is pervasive (c) and ooid dissolution more advanced (arrowed and d, where ooid is partially cemented and replaced). In Well $D$, interparticle calcite cementation is pervasive and compaction is evidenced by grain-grain contacts (arrowed). The sample is cut by a calcite cemented fracture (e).

Figure $5 \mathrm{~A}$ ) Changes in porosity and permeability by depth in well I, based on depth beneath the USB (ie. beneath top reservoir) B) variation in porosity and permeability by Facies Association (all wells) Note that the best reservoir properties are within bioturbated and planar laminated oolitic grainstones (PGob and Gol) but that facies association does not explain all the variation in porosity and permeability C) relationship between macroporosity and $\mathrm{Kh}$, with an overall improvement in permeability as macropore volume increases, particularly in Facies Association PGob and Gol (Key as for B) D) relationship between micropore volume and abundance of altered ooids by Facies Association (Key as for B). Note that the abundance of micoporosity neither improves nor degrades permeability suggesting that it makes some contribution to permeability in some facies E) relationship between ooid volume and micropore volume, showing that the volume of microporosity increases with an increase in the volume of microporous ooids; ie. alteration of ooids is the principle control on micropore volume

Figure 6 Types of porosity in Upper Arab D A) Intraparticle micro- and macroporosity (yellow arrow) and partially cemented oomould (a) within cemented oolitic grainstone B) Intraparticle macroporosity (a) and intraparticle microporosity (b) within ooid. Note cements penetrating altered ooid (arrowed) and fused microcrystalline calcite at core of ooid C) partially cemented biomoulds after bivalves (arrows) D) intrparticle microporosity in ooid cortices (arrowed) and cemented fractures (c)) E) Partially cemented 
intraparticle macropore (yellow box), note that outer cortex has been spalled during compaction (arrow) whilst ooid core is tightly cemented by microcrystalline calcite (a) F) BSEM image of ooid with leached, microporous cortex (a) and fused, calcite cemented core (b)

Figure 7A) Unaltered ooids with minor interparticle calcite cement, Bioturbated Grainstone FA in Well? B) Micropoous ooid with recrystallised core and equant, sparry calcite penetrating outer ooid cortex (yellow arrow) and compacted grains where no cementation (white arrow), Well ? C) and D) paired plane light and cathodoluminescence image of altered oolitic grainstone with grain rimming calcite cement (arrowed) and dull luminescent equant sparry calcite (a). E and $F$, paired plane light and $C L$ image of calcite cemented fracture with dull luminscent equant, sparry calcite fill (c)

Figure $8 \mathrm{~A}) \delta^{18} \mathrm{O}$ vs $\delta^{13} \mathrm{C}$ for all whole rock samples from Arab D and calcite cements. B) $\delta^{18} \mathrm{O}_{\text {calcite }}$ and $\delta^{13} \mathrm{C}_{\text {calcite }}$ plotted against volume of non-skeletal grains (green triangles), matrix (blue diamonds) and total matrix pore filling cements (red squares) C) Isotope fractionation curve s (solid lines) showing the relationship between temperature and $\delta^{18} \mathrm{O}_{\text {water }}$ for $\delta^{18} \mathrm{O}_{\text {calcite }}=-5+1 \%$ based on Friedman and $\mathrm{O}^{\prime}$ Neil (1977) The dotted lines show were calculated according to Swart (2015) and show that Jurassic seawater with an initial composition of $\delta^{18}$ OSMOW $=-1 \%$ SMOW could evolve under closed system conditions to a fluid of $\sim+2 \%$ SMOW (arrow) that precipitated calcite with $\delta^{18} \mathrm{O}=-5+1 \%$ (dotted lines), as observed in the upper Arab D reservoir, at fluid temperatures of $\sim 30-60^{\circ} \mathrm{C}$ (red box).

Figure 9A) Rare Earth Element profile for whole rock oolitic grainstone (A) and B) $\mathrm{Ce} / \mathrm{Ce}$ * vs $\mathrm{Pr} / \mathrm{Pr}$ * plot for all samples. Where data falls in the bottom right-hand quadrant, a marine seawater origin is interpreted (Hayley et al., 2000). Key as for C and D (C) Mn and Fe concentration for upper Arab D member, lower Arab D member (skeletal wackestone), upper and lower sequence boundary (USB and LSB) and calcite cemented fractures (D) Mg and Sr concentration upper Arab D member, lower Arab D member (skeletal wackestone), upper and lower sequence boundary (USB and LSB) and calcite 
cemented fractures.

Figure 10 Trace element maps for $\mathrm{Mg}(\mathrm{A}$ and $\mathrm{B})$, BSEM images ( $\mathrm{C}$ and $\mathrm{D})$ and trace element profiles (E and F) for two samples from Well C collected by electron probe micro-analysis. In trace element profiles, $\mathrm{Mg}$ is red, $\mathrm{Mn}$ is green, $\mathrm{Fe}$ is purple and $\mathrm{Sr}$ is blue. E) Homogenisation temperatures from aqueous fluid inclusions within calcite cements within the Arab D Member in Wells A (blue), B (green) and C (red)

Figure 11 Porosity evolution of the Upper Arab D Member. See text for explanation. 


\begin{tabular}{|c|c|c|c|c|}
\hline $\begin{array}{c}\text { Facies } \\
\text { Association }\end{array}$ & Texture and composition & $\begin{array}{l}\text { Sedimentary } \\
\text { and biogenic } \\
\text { structures }\end{array}$ & Stacking pattern & $\begin{array}{l}\text { Depositional } \\
\text { environment }\end{array}$ \\
\hline $\begin{array}{l}\text { Bioturbated } \\
\text { oolitic pack- } \\
\text { grainstone } \\
\text { (PGob) }\end{array}$ & $\begin{array}{l}\text { Dominant fine - medium } \\
\text { grained, well sorted, } \\
\text { oolitic grainstone and } \\
\text { minor oolitic packstone }\end{array}$ & $\begin{array}{l}\text { Millimetre - } \\
\text { centimetre } \\
\text { scale } \\
\text { Thallassinoides- } \\
\text { type burrows }\end{array}$ & $\begin{array}{l}\text { Amalgamated } \\
\text { packages, } 1.5 \mathrm{~m} \\
\text { thick, trendless or } \\
\text { weakly upward } \\
\text { fining / muddying }\end{array}$ & $\begin{array}{l}\text { Moderate energy, } \\
\text { gently agitated } \\
\text { lagoon }\end{array}$ \\
\hline $\begin{array}{l}\text { Planar } \\
\text { laminated } \\
\text { oolitic } \\
\text { grainstone } \\
\text { (Gol) }\end{array}$ & $\begin{array}{l}\text { Fine - medium grained, } \\
\text { moderately well sorted } \\
\text { skeletal (bivalve, benthic } \\
\text { foraminifera) oolitic } \\
\text { grainstone }\end{array}$ & $\begin{array}{c}\text { Planar } \\
\text { laminated, } \\
\text { alternations of } \\
\text { fine grained } \\
\text { ooids and } \\
\text { medium } \\
\text { grained skeletal } \\
\text { allochems }\end{array}$ & $\begin{array}{l}\text { } 1.5 \mathrm{~m} \text { thick, } \\
\text { trendless or } \\
\text { weakly upward } \\
\text { fining / muddying } \\
\text { beds stacked into } \\
\sim 7.5 \mathrm{~m} \text { thick } \\
\text { packages }\end{array}$ & $\begin{array}{l}\text { Tidal sand bar or } \\
\text { flood-tidal delta }\end{array}$ \\
\hline $\begin{array}{l}\text { Trough cross- } \\
\text { bedded } \\
\text { grainstone } \\
\text { (Got) }\end{array}$ & $\begin{array}{l}\text { Oolitic skeletal } \\
\text { grainstone, comprosing } \\
\text { fine - medium grained } \\
\text { ooids and coarse grained } \\
\text { skeletal debris (coral- } \\
\text { algal, bivalve, echinoid, } \\
\text { benthic foraminifera) }\end{array}$ & $\begin{array}{l}\text { Well defined, } \\
\text { low angle bi- } \\
\text { directional } \\
\text { trough cross- } \\
\text { bedding }\end{array}$ & $\begin{array}{l}\text { Usually thick (up } \\
\text { to } 15 \mathrm{~m} \text { ) subtly } \\
\text { upward-fining / } \\
\text { muddying } \\
\text { packages, often } \\
\text { scoured bases } \\
\text { hosting pebble- }\end{array}$ & $\begin{array}{l}\text { Sinuous, parabolic } \\
\text { sand bars formed } \\
\text { under strongly } \\
\text { tidal conditions. } \\
\text { Erosive bed bases } \\
\text { may indicate } \\
\text { dissection of the }\end{array}$ \\
\hline
\end{tabular}




\begin{tabular}{|c|c|c|c|c|}
\hline & & & grade intraclasts & $\begin{array}{c}\text { barforms by tidal } \\
\text { channels }\end{array}$ \\
\hline $\begin{array}{c}\text { Molluscan } \\
\text { planar } \\
\text { laminated and } \\
\text { bedded pack- } \\
\text { grainstone } \\
\text { (PGml) }\end{array}$ & $\begin{array}{l}\text { Fine - medium grained, } \\
\text { moderately well sorted } \\
\text { skeletal pack-grainstone } \\
\text { with abundant bivalves } \\
\text { and echinoid debris }\end{array}$ & $\begin{array}{l}\text { Planar } \\
\text { laminated and } \\
\text { bedded }\end{array}$ & $\begin{array}{l}\text { Trendless to } \\
\text { weakly upward } \\
\text { fining/ muddying } \\
\text { beds, }<1.5 \mathrm{~m} \text { thick }\end{array}$ & $\begin{array}{c}\text { Upper slope, } \\
\text { moderately deep } \\
\text { and/or turbid } \\
\text { water }\end{array}$ \\
\hline $\begin{array}{l}\text { Peloidal } \\
\text { packstone } \\
\text { (Pp) }\end{array}$ & $\begin{array}{l}\text { Packstone dominated by } \\
\text { fine grained peloids with } \\
\text { subordinate benthic } \\
\text { foraminifera, molluscan } \\
\text { and echinoid debris }\end{array}$ & $\begin{array}{l}\text { Massive or } \\
\text { weakly } \\
\text { bioturbated }\end{array}$ & $\begin{array}{l}\text { Trendless to } \\
\text { weakly upward } \\
\text { coarsening/ } \\
\text { cleaning beds, } \\
\text { usually <1.5 m } \\
\text { thick }\end{array}$ & Upper slope \\
\hline $\begin{array}{c}\text { Lime } \\
\text { mudstone(MI) }\end{array}$ & Lime mudstone & Massive & $\begin{array}{c}\text { Trendless and } \sim 1.5 \\
\text { m thick }\end{array}$ & $\begin{array}{l}\text { Upper slope to } \\
\text { basin }\end{array}$ \\
\hline
\end{tabular}

Table 1 Summary of Lithofacies Associations in the Arab D (Upper) reservoir 


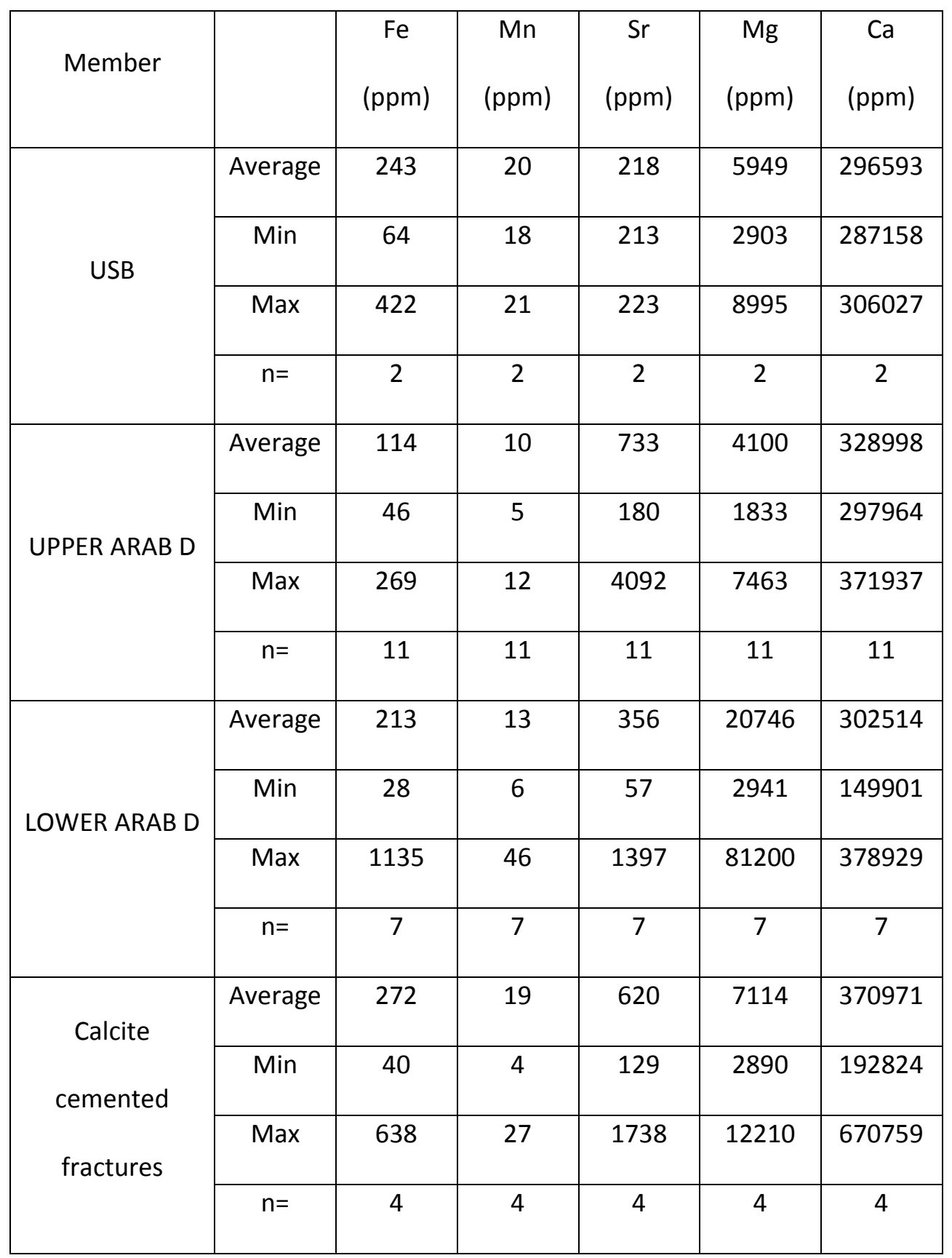

Table 2 Summary of major ion concentrations in Upper Arab D Member 

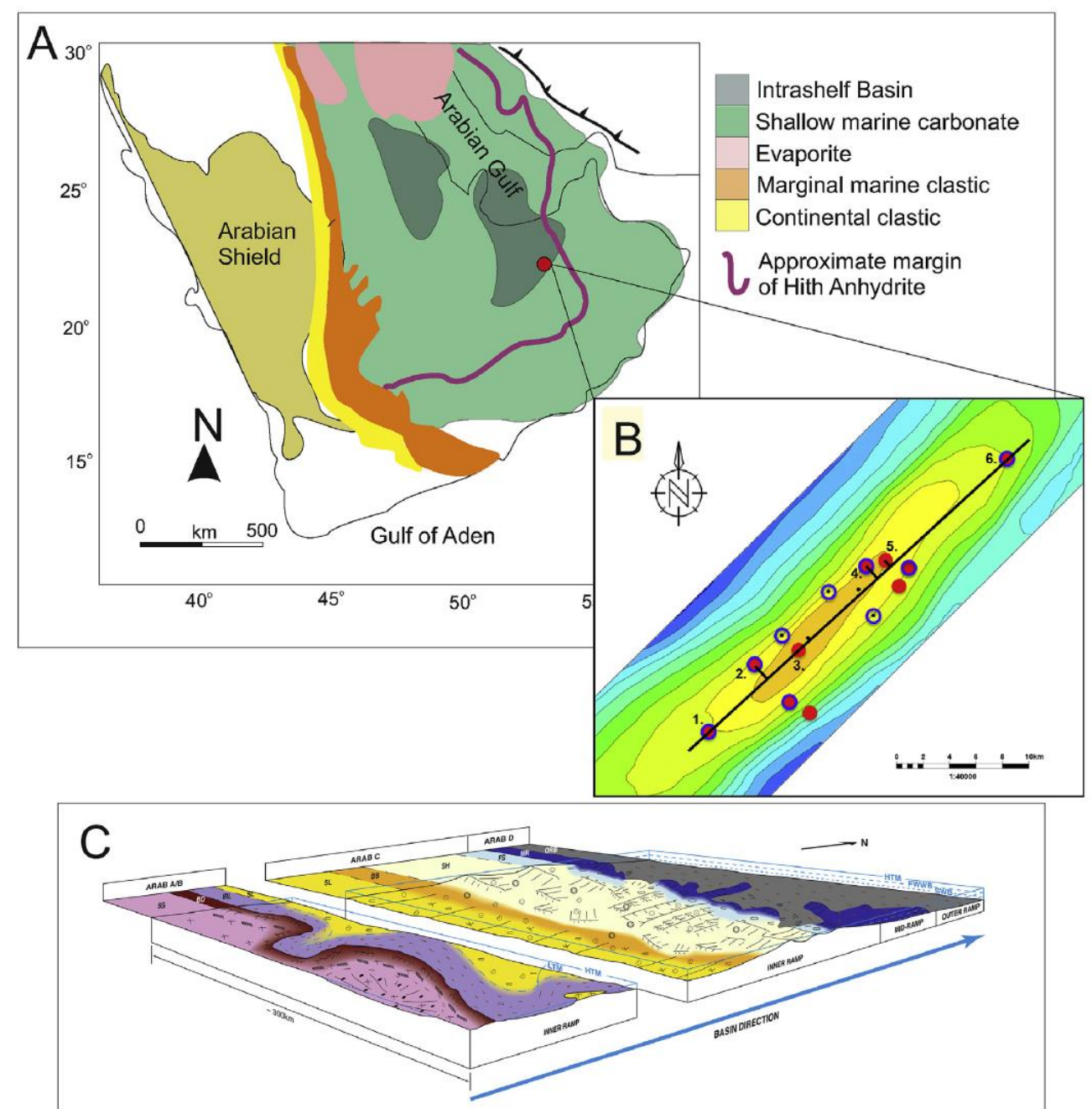

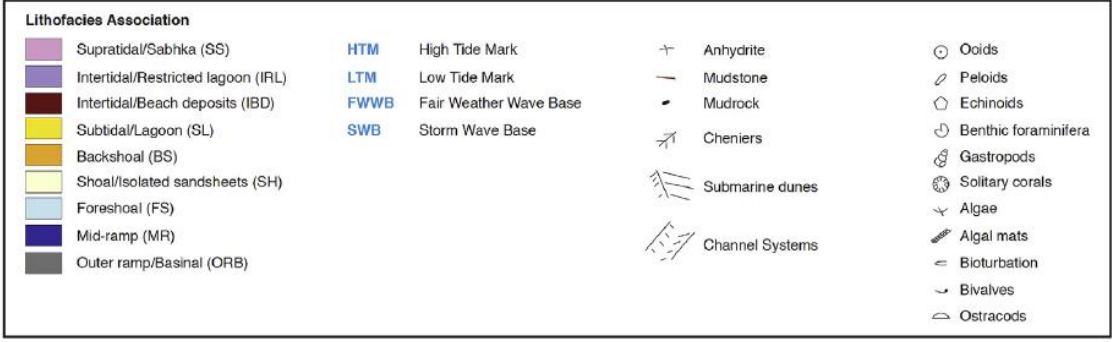

Figure 1 


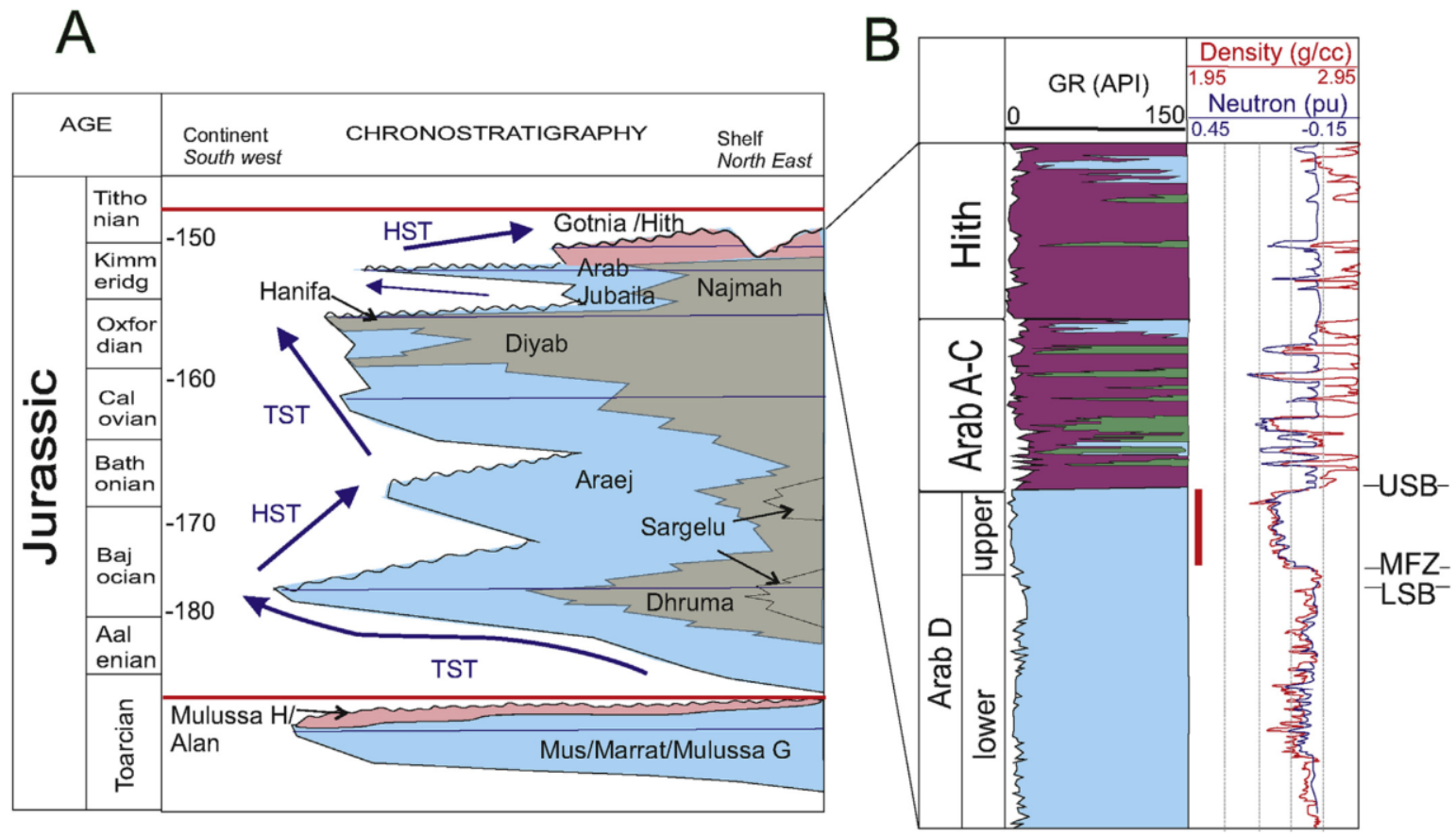

Figure 2 


\section{A}

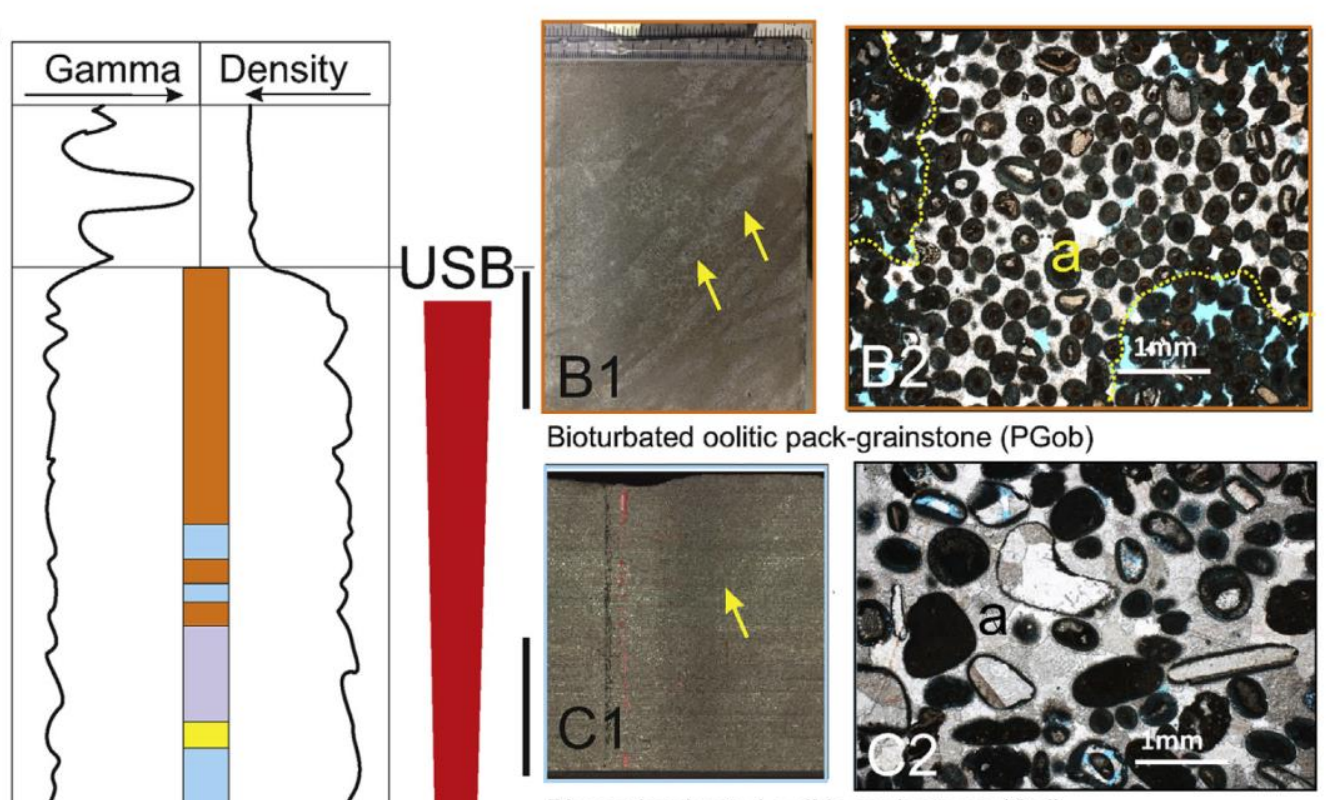

Planar laminated oolitic grainstone (Gol)

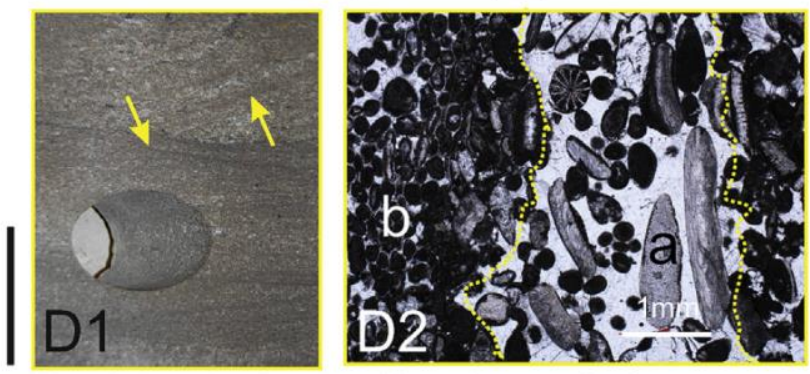

Trough cross laminated oolitic grainstone (Got)
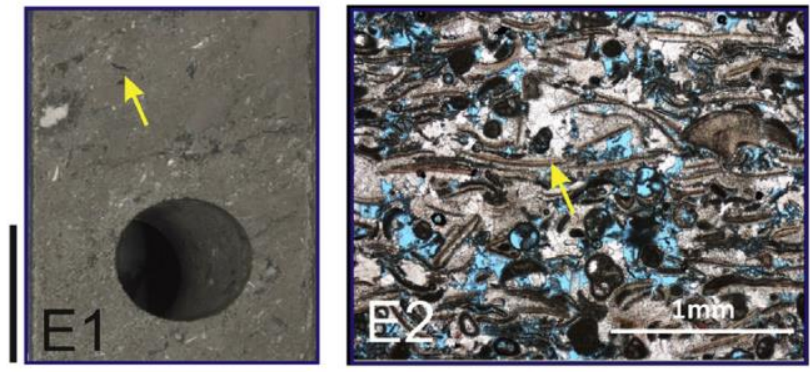

Molluscan planar laminated pack-grainstone (PGml)

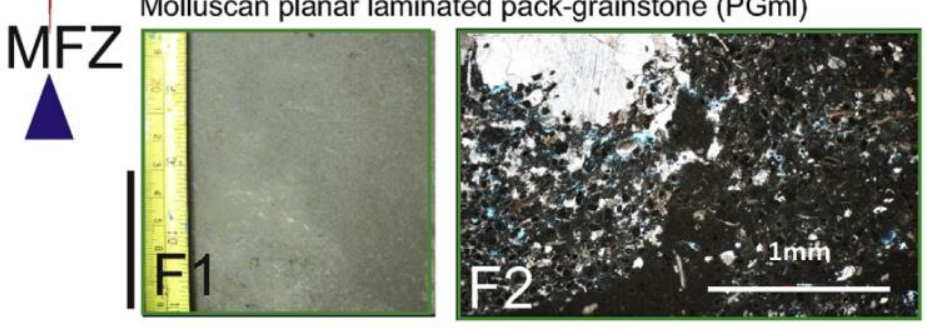

Peloidal packstone (Pp)

Figure 3 

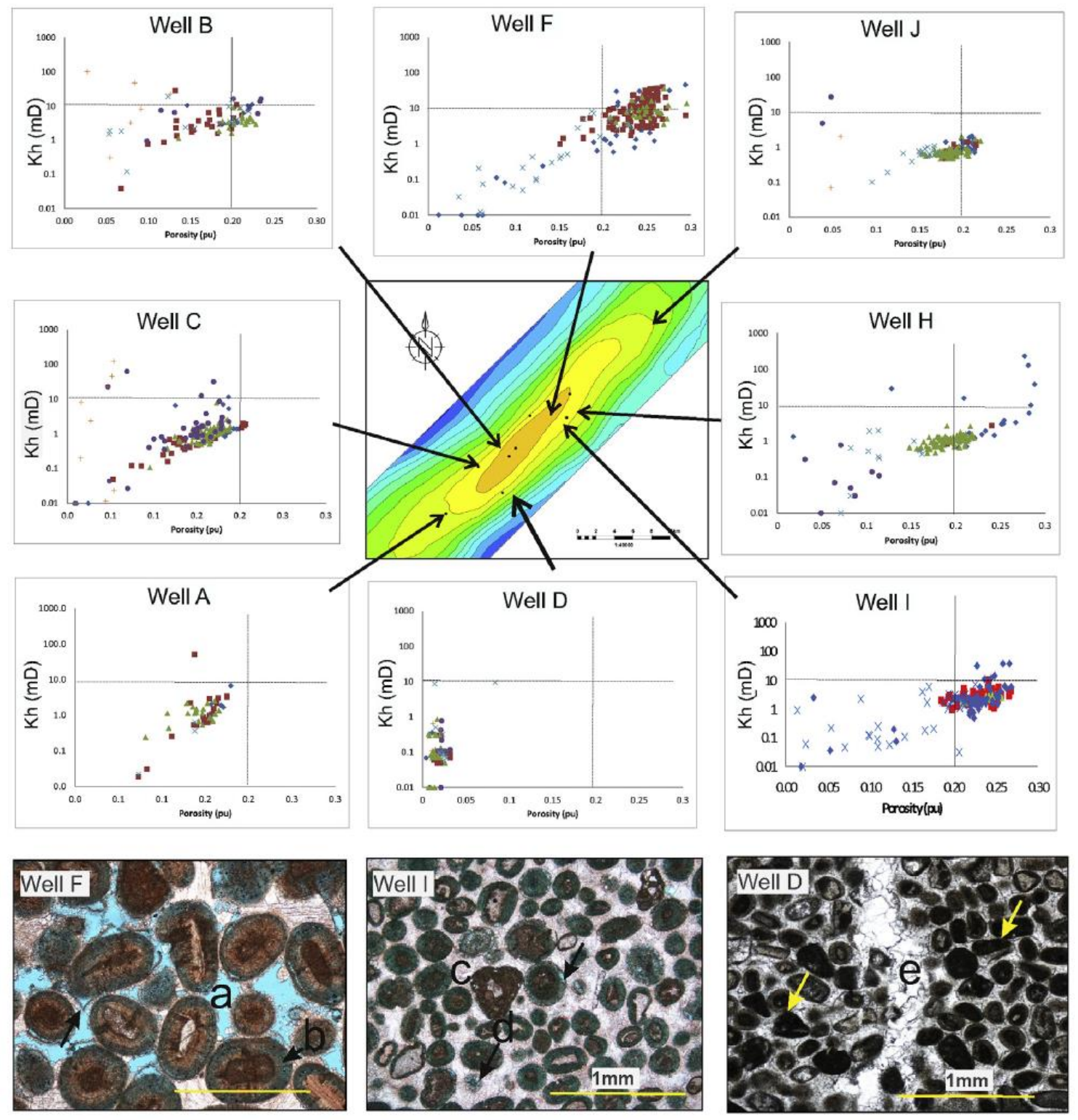

\begin{tabular}{|l|}
\hline PGbo \\
口 Gol \\
- Got \\
PGml \\
$\times \mathrm{Pp}$ \\
$+\mathrm{Ml}$ \\
\hline
\end{tabular}

Figure 4 

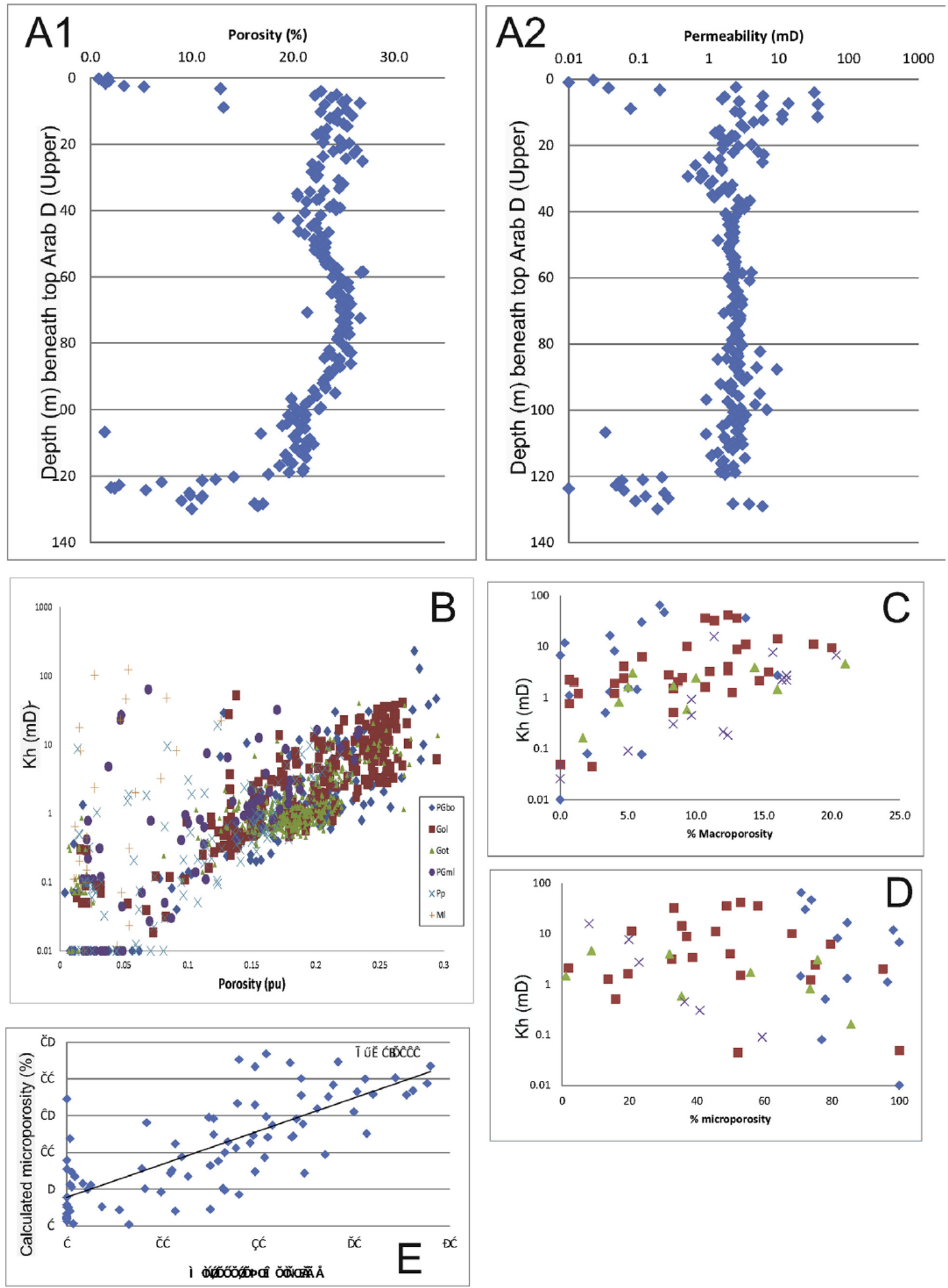

Figure 5 

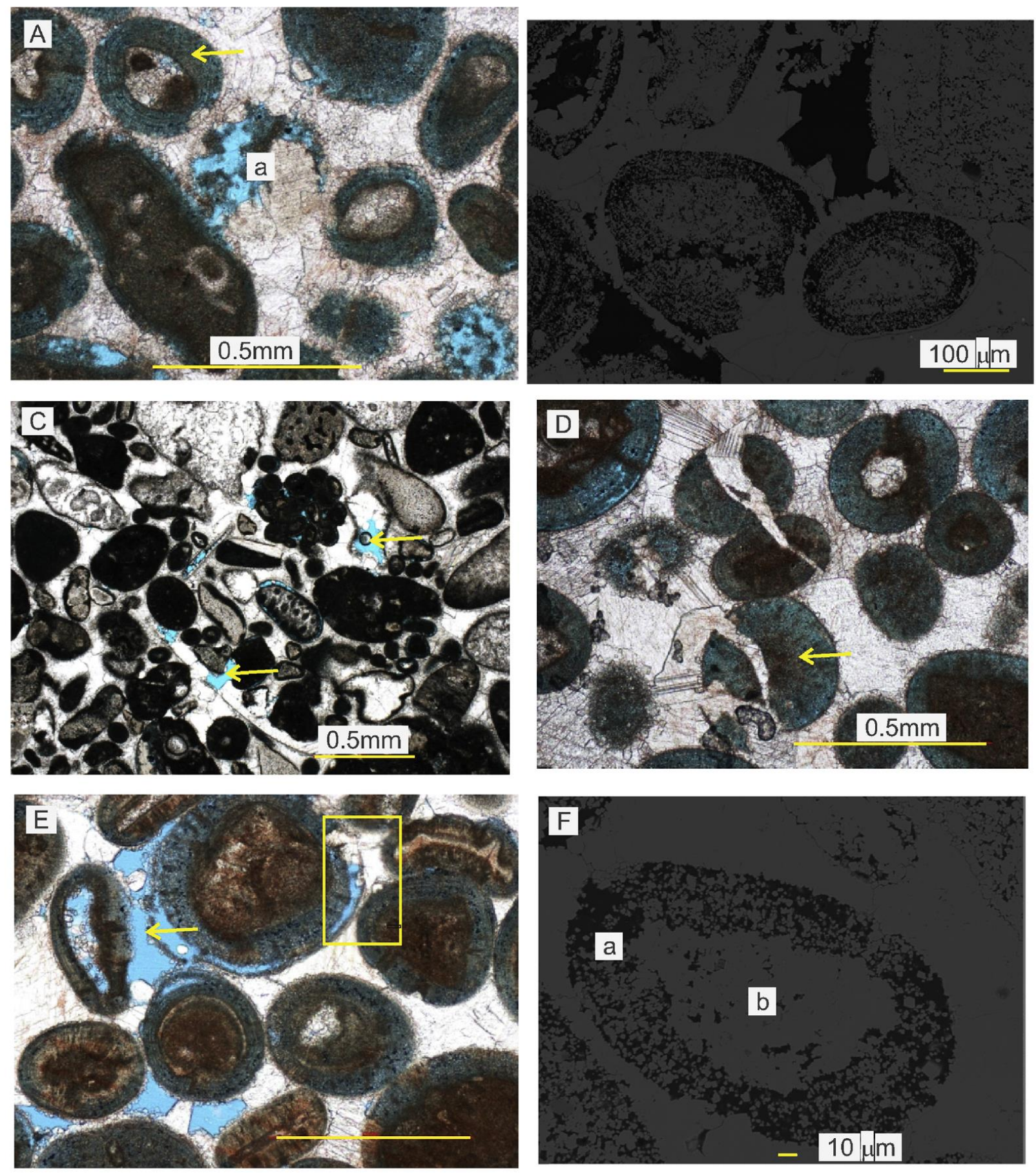

Figure 6 

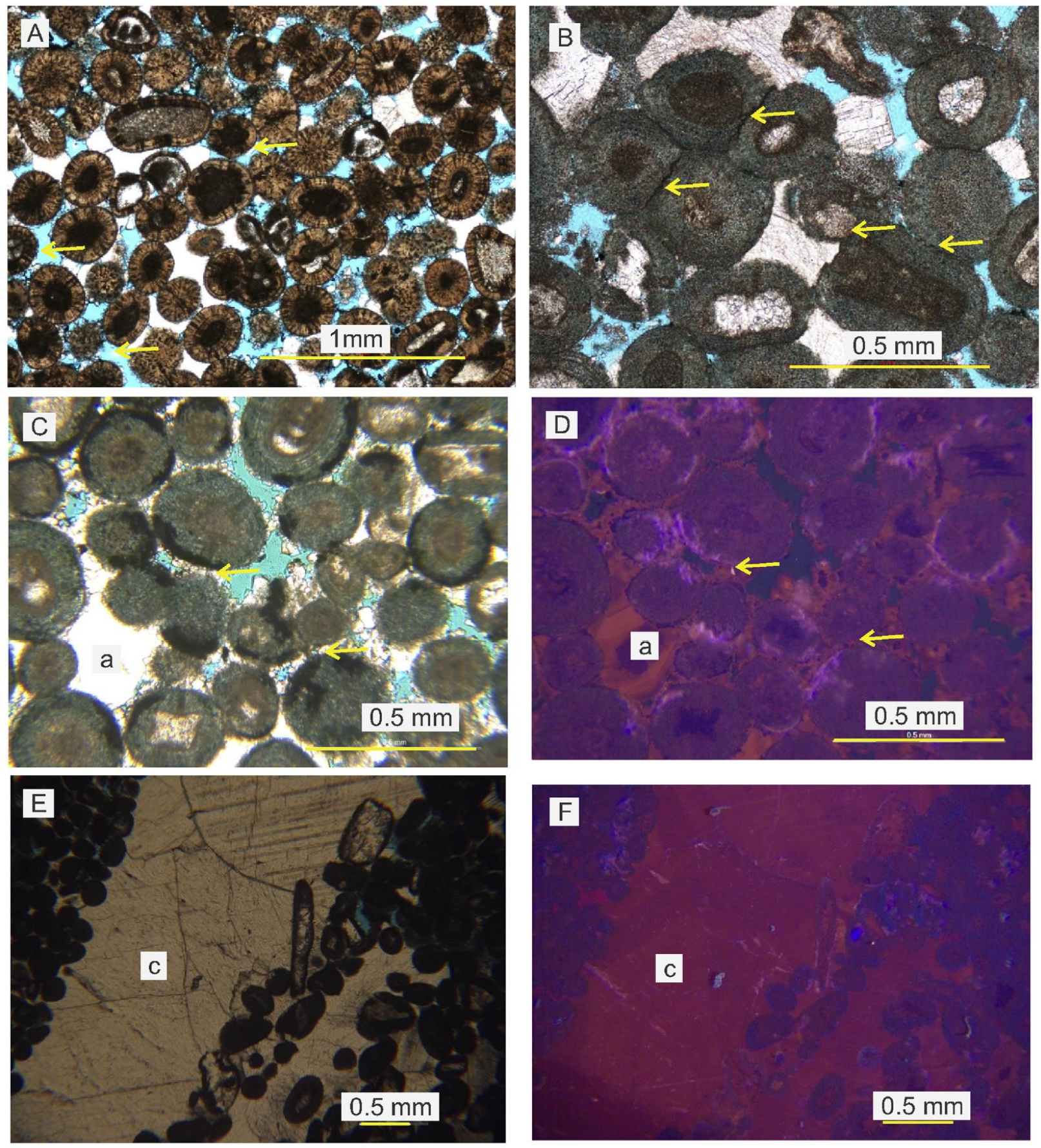

Figure 7 

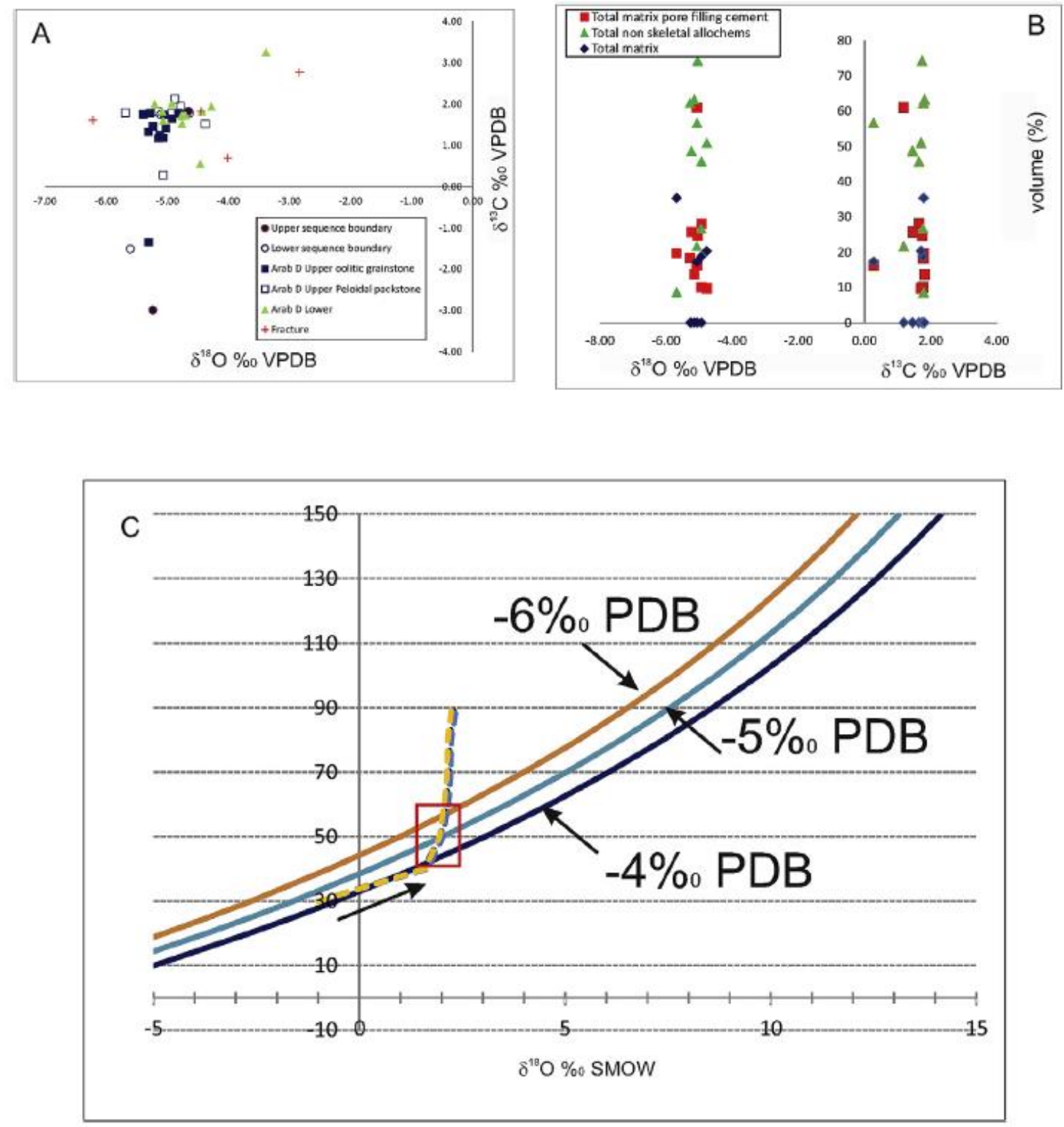

Figure 8 

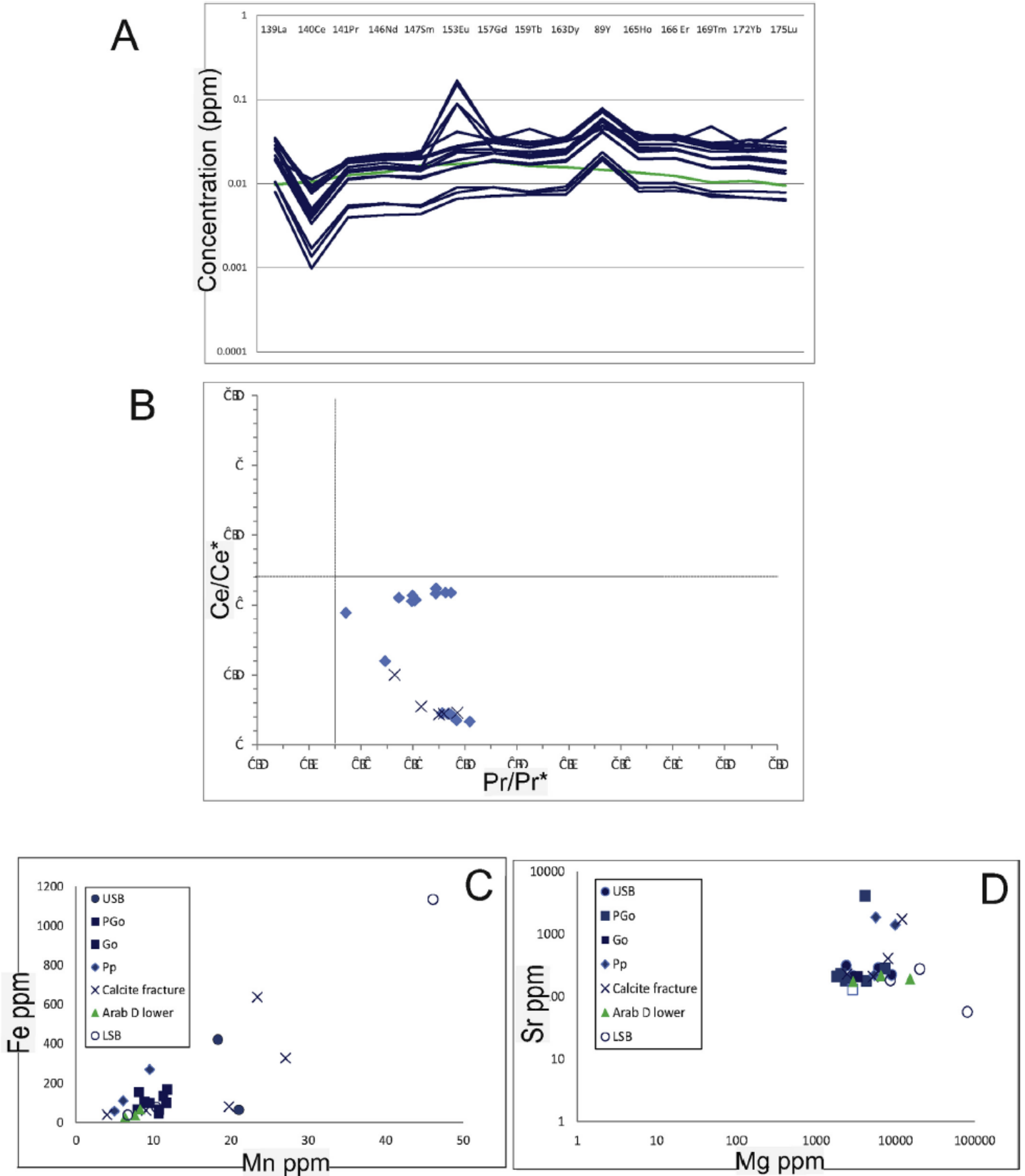

Figure 9 

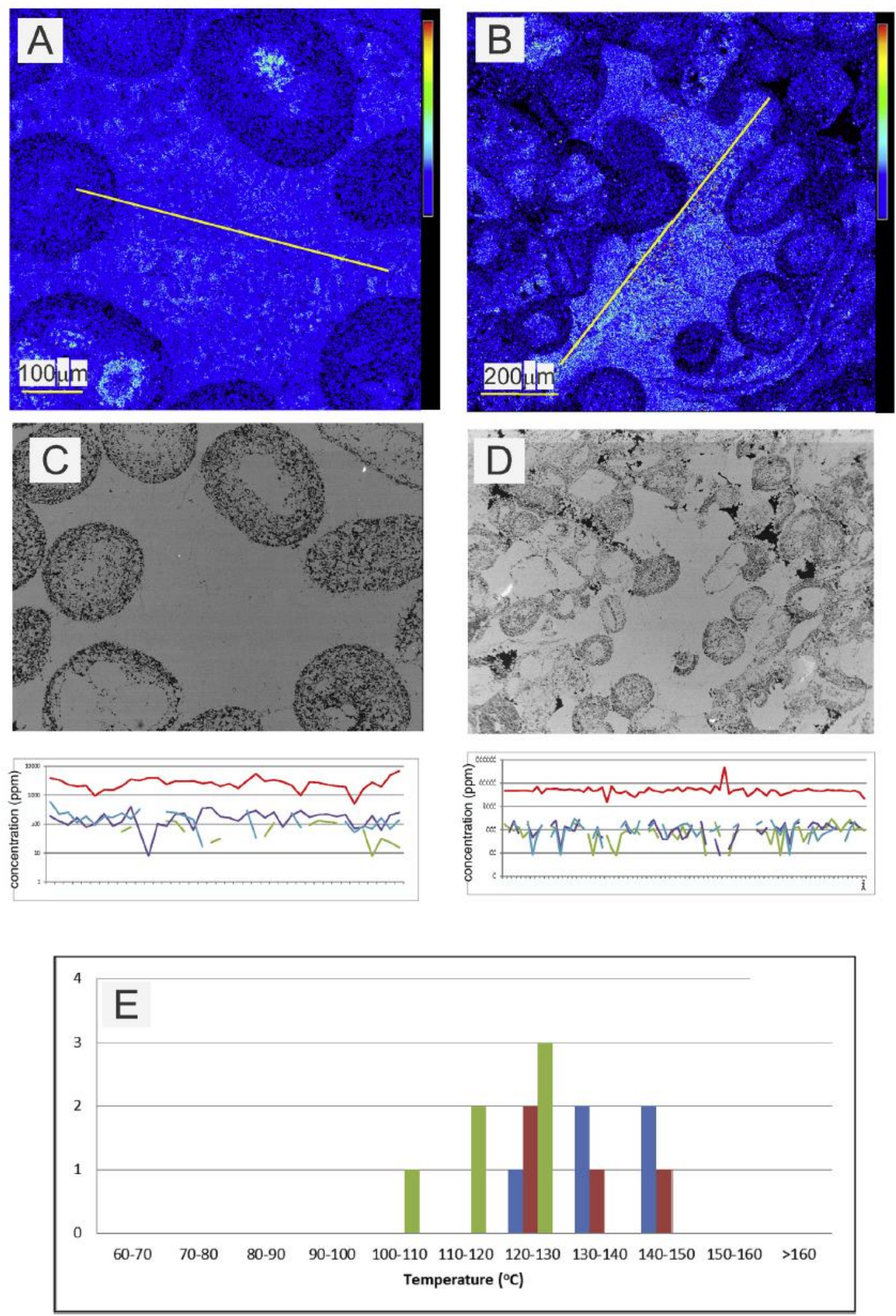

Figure 10 


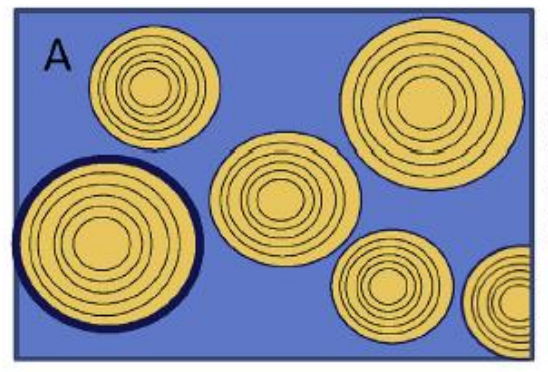

A) Clean oolitic grainstone with aragonitic ooids (brown), some with thin coating of calcite cement (thick blue rim), and high interparticle porosity (blue). Where ooids remain unaltered, perhaps because of early hydrocarbon charge (E3) and/or primary calcitic composition subsequent diagenetic events are inhibited and high interparticle pore volumes are retained

B) Initiation of aragonite transformation on outer cortices (green). Disequilibrium is driven by the higher solubility of

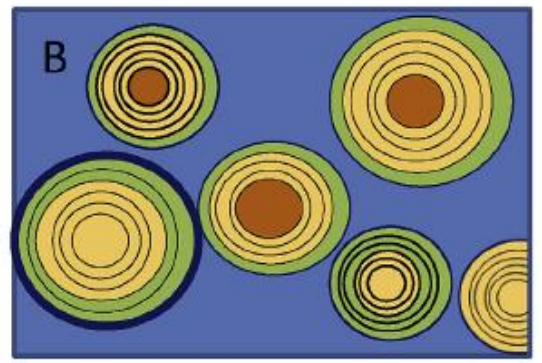
aragonite than calcite and facilitated by organic matter oxidation and bacterial sulphate reduction beneath sedimentwater interface. Dense microcrystalline LMC precipitated in ooid core (dark brown), becoming microporous on rim (green).

C) Continued diffusion of calcite-saturated fluid towards centre of ooid, precipitating dense, fused microcrystalline calcite (dark brown) and diffusion of saturated fluids away from grain via interparticle macroporosity
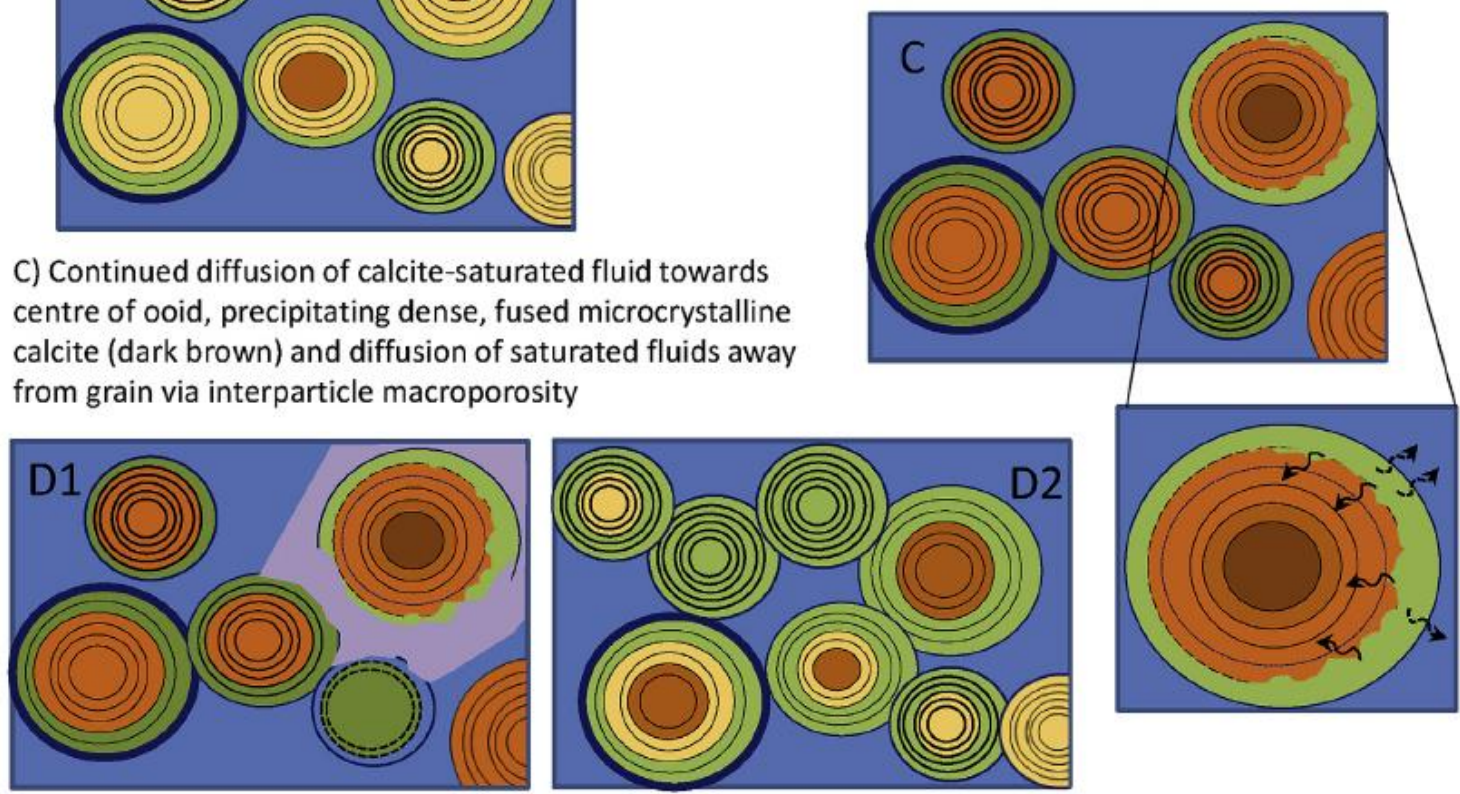

D1) Increasing fluid saturations through much of the section lead to calcite precipitation in interparticle macropores (purple) D2) Where aragonite transformation is inhibited or where interparticle pores are well connected, no local precipitation of coarsely crystalline calcite and compaction is more intense.
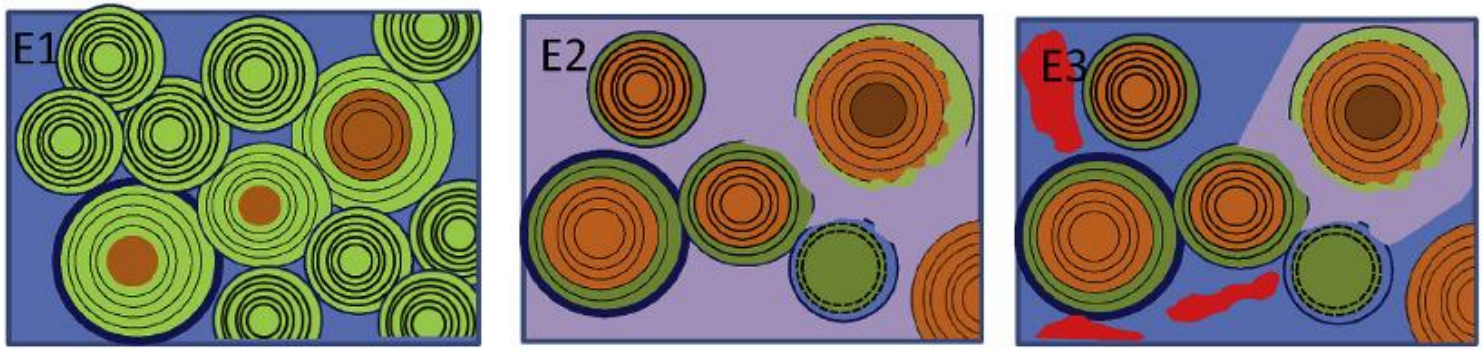

E1 Where minor or no calcite cement, microporous ooids become highly compacted and porosity is reduced. Where cementation is pervasive (E2) interparticle macroporosity is occluded by calcite. On the palaeocrest of the field, hydrocarbon ingress (red) alters wettability and terminates diagenesis

Figure 11 